\title{
INFLUÊNCIA DE ÉPOCAS E DOSES DE ADUBAÇÃO NITROGENADA NA PRODUÇÃO ESTACIONAL DE DOIS CAPINS
}

\author{
MICHELLE NAZARÉ XAVIER DA COSTA \\ Engenheiro Agrônomo
}

Orientador: Prof. Dr. HERBERT BARBOSA DE MATTOS

\begin{abstract}
Dissertação apresentada à Escola Superior de Agricultura "Luiz de Queiroz", Universidade de São Paulo, para obtenção do título de Mestre em Agronomia, Área de Concentração: Ciência Animal e Pastagens.
\end{abstract}

PIR A C I C A B A

Estado de São Paulo - Brasil

Novembro - 1999 
Dados Internacionais de Catalogaçāo na Publicaçāo (CIP)

\section{DIVISÃo DE BIBLIOTECA E DOCUMENTAÇÃO - Campus "Luiz de Queiroz"/USP}

\section{Costa, Michelle Nazaré Xavier da} Influência de épocas e doses de adubação nitrogenada na produçāo estacional de dois capins / Michelle Nazaré Xavier da Costa. - - Piracicaba, 1999.

$67 \mathrm{p}$.

Dissertaçāo (mestrado) - : Escola Superior de Agricultura Luiz de Queiroz, 1999. Bibliografia

1. Adubação nitrogenada 2. Capim mombaça 3. Capim quicuio 4. Dosagem 5. Época de aplicaçāo 6. Graminea 6. Matéria seca 7. Nitrogênio I. Título

CDD 633.2 
Gada dia é um nour cameca;

Paxa realinax mais,

da que fensámamas que conseguixímos,

fuaxa sex mais da que acreditáramas,

fara sex mais,

sempere mais

do que famos antes. 
Alas meus pais, Olinia e Varaxeth Gasta, que estiveram sempere pexesentes ao men lado em todas as etafeas de mintea vida sendo exempelos de fresca, coragem e determinacaio.

Dedico

Alos meus irmãos Michell e Marcus e a todos os meus familiaxes pelo apoio, amox e compexeensão em lodos as momentos.

Dedica

He Hânica, Moerna, Kathya e Piedade pelos momentos de alegria e solidariedade, através da convinência na cextera de que sempire sevemas etermos amigas.

Ofereco 


\section{AGRADECIMENTOS}

* A Deus pela proteção, luz, força e ajudar-me a superar todas as adversidades.

* À Escola Superior de Agricultura "Luiz de Queiroz" e Curso de Pós-Graduação em Ciência Animal e Pastagens pela oportunidade deste treinamento.

- À Faculdade de Ciências Agrárias do Pará, através da Unidade de Apoio à Pesquisa e Pós-Graduação (programa PICDT/CAPES) pela concessão da bolsa de estudos.

* Ao prof. Dr. Herbert Barbosa de Mattos, pelo incentivo, atenção, confiança e amizade, ao me permitir caminhar e escolher o percurso trilhado.

* À Manah Agropastoril, na pessoa do Eng. Agro. Sr. Eduardo Penteado Cardoso, pela concessão das áreas experimentais, bem como, apoio durante todo 0 período do experimento.

* Aos funcionários da Fazenda Mundo Novo - Manah Agropastoril, pela ajuda na condução do experimento, nas pessoas dos Engs. Agrônomos, Pedro Seber e Carlos, Magnum, Sr. Laerte, Vanilson, Clodoaldo e Dna. Lena.

* Ao Instituto de Zootecnia, através da Estação Experimental - Brotas, na pessoa do Eng. Agr. Vanderley B. de O. Leite, pelo apoio durante a condução do experimento.

* Ao Departamento de Produção Animal da ESALQ/USP, em especial aos professores Waldomiro Shigueru Miyada, Irineu Umberto Packer, Sila Carneiro da Silva e aos funcionários: Cesar, Cláudia, Vera e Cleide que contribuíram de alguma forma para a realização do trabalho.

* Aos funcionários do Laboratório de Nutrição Mineral de Plantas - ESALQ/USP, Lourdes e Nivanda pela paciência na execução das análises.

* Ao prof. Dr. Tadeu dos Santos Dias pelo importante auxílio na elaboração das análises estatísticas.

* À bibliotecária Eliana M. Garcia Sabino pela revisão das referências bibliográficas e a todos os funcionários do setor de empréstimo da biblioteca pela prestatividade.

* Aos funcionários do Setor de Transportes - ESALQ/USP, pela prestação dos serviços.

* A todos os colegas do Curso de Ciência Animal e Pastagens - ESALQ, pelo convívio durante a realização do mestrado. 
* Ao amigo Vicente Paulo Martello, pela amizade, ajuda e apoio durante a fase de campo.

- A José Eduardo Boffino de Almeida Monteiro, a minha gratidão por me ajudar a manter o equilíbrio, pela compreensão e carinho permanecendo junto a mim nos momentos dificeis.

* A Paulo, Dênmora, Edson, Gerlane, Cláudia, Rainério, Edson Tafuri, Mônica, Tatiana, Cristina, Viviane, Juliana, Andréa, pelo apoio recebido e por todos os momentos que compartilhamos juntos.

* A Marcelo E. Alves e Rosângela C.M. Pena pela enorme ajuda prestada nos momentos de "socorro".

* À Dra. Therezinha Xavier Bastos e Dr. Miguel Simão Neto, pelo incentivo dado desde o início de minha carreira.

- A todos aqueles que, de alguma forma, contribuíram com a realização deste trabalho. 


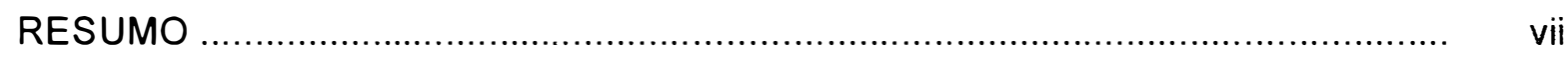

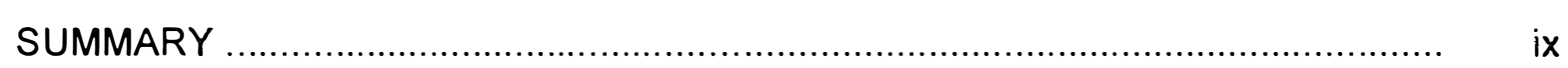

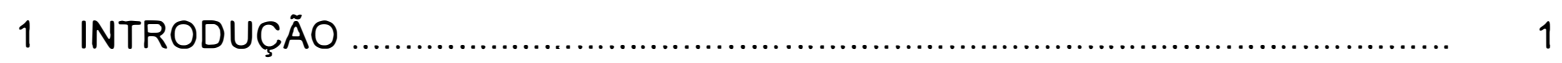

2 REVISÃO DE LITERATURA …..................................................................... 3

2.1 Origem e caracterização................................................................................. 3

2.1.1 Panicum maximum cv. Mombaça...................................................................................

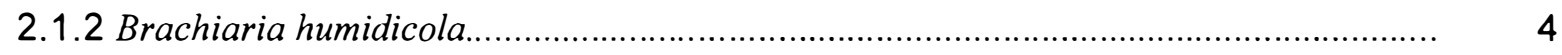

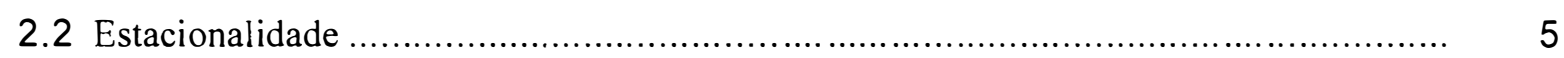

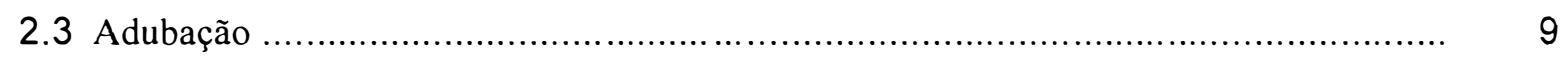

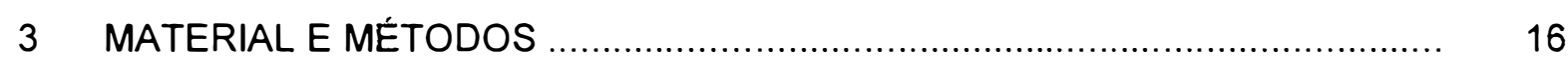

3.1 Localização do experimento............................................................................ 16

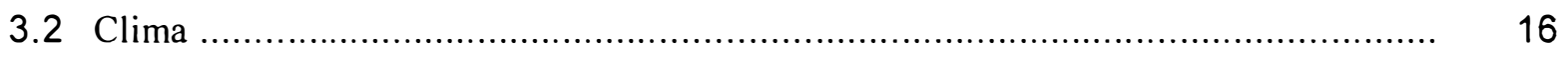

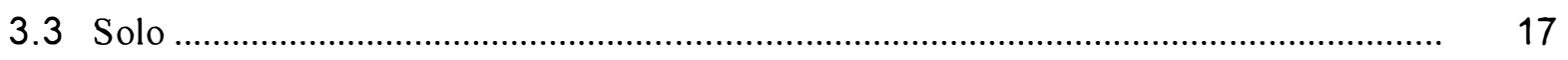

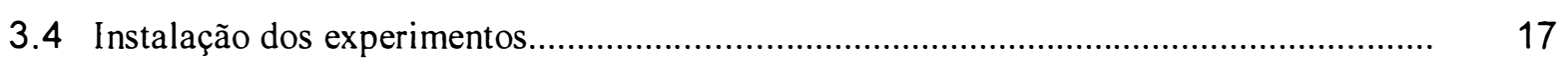

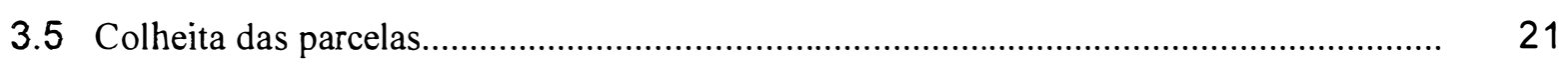

3.6 Análises estatísticas............................................................................................... 24

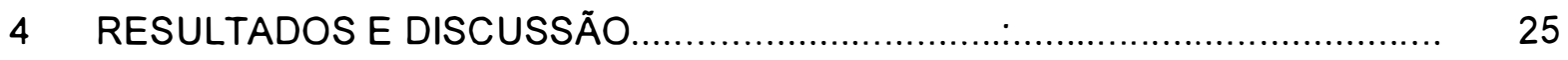

4.1 Panicum maximum cv. Mombaça.............................................................................. 25

4.1.1 Produção de forragem.............................................................................................. 25

4.1.2 Composição bromatológica........................................................................................ 26

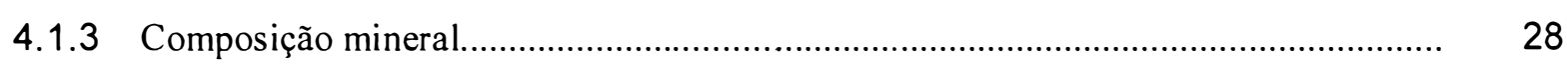

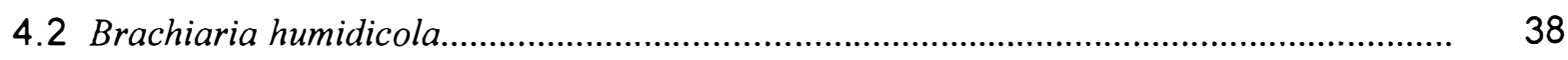

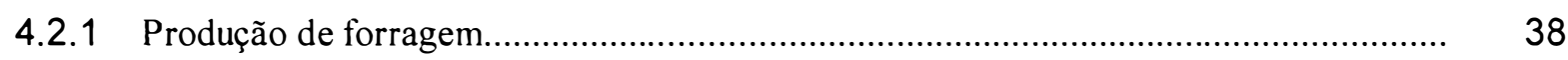

4.2.2 Composição bromatológica..................................................................................... 39

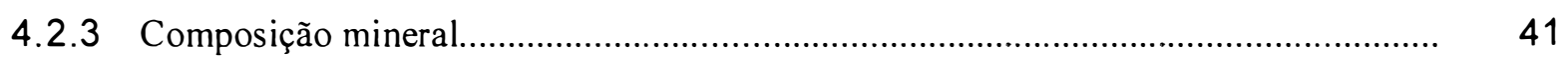

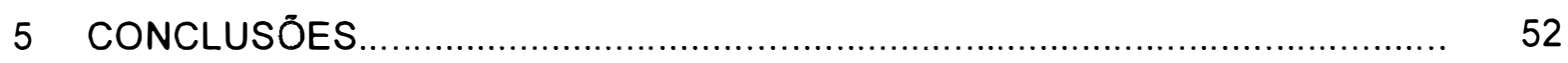

5.1 Panicum maximum cv. Mombaça.................................................................................. 52

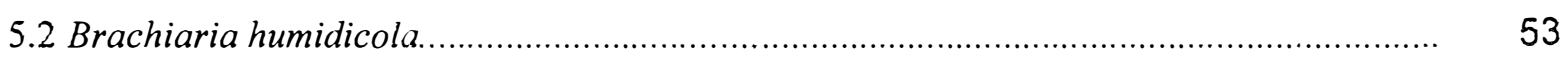

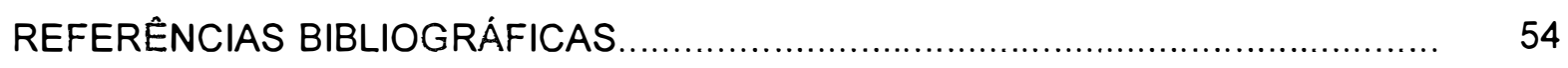




\title{
INFLUÊNCIA DE ÉPOCAS E DOSES DE ADUBAÇÃO NITROGENADA NA PRODUÇÃO ESTACIONAL DE DOIS CAPINS
}

\author{
Autora: MICHELLE NAZARÉ XAVIER DA COSTA \\ Orientador: Prof. Dr. HERBERT BARBOSA DE MATTOS
}

\section{RESUMO}

O presente trabalho teve por objetivo avaliar a produção estacional dos capins Panicum maximum cv. Mombaça e Brachiaria humidicola submetidos à diferentes épocas e doses de adubação nitrogenada. Para tanto, experimentos de campo foram realizados adotando-se o delineamento experimental em blocos casualizados em esquema fatorial, visando um estudo conjunto dos efeitos de doses de nitrogênio (50, 100 e $150 \mathrm{~kg} \mathrm{ha}^{-1}$ ), épocas de aplicação ( total em novembro, 1/2 em novembro e $1 / 2$ em março e 1/3 em novembro e 2/3 em março) e periodos ( "verão" e "inverno") sobre as produções de matéria seca (MS) e composição química de ambos.

Os resultados obtidos indicaram que o capim Panicum maximum cv. Mombaça não apresenta melhor distribuição de produção de matéria seca entre os periodos, em função de doses e épocas de aplicação de N. As doses e épocas de aplicação de nitrogênio não proporcionaram diferenças entre nos teores de proteina bruta (PB), que por sua vez foram maiores no período de "verão". De modo similar, observou-se efeito do período sobre a composição mineral das plantas. Os teores de nitrogênio, fósforo, potássio e enxofre foram maiores no "verão" ao passo que cálcio e magnésio o foram no "inverno". O exame das relações entre teores de nutrientes revelaram que a relação N/S foi maior nas épocas parceladas enquanto que a relação $C a / P$ foi maior no periodo de "inverno". 
O capim Brachiaria humidicola teve a sua distribuição de produção de matéria seca influenciada pelas épocas de aplicação com maiores produções no periodo de "verão". A aplicação $1 / 3$ da dose de $\mathrm{N}$ em novembro e $2 / 3$ em março proporcionou melhoria na distribuição de produção de matéria seca ( $78 \%$ no "verão" e $22 \%$ no "inverno"). Os teores de PB também sofreram efeito da estacionalidade apresentandose maiores no periodo de "inverno" com a aplicação parcelada de N. Com exceção do $\mathrm{N}$, todos os macronutrientes apresentaram-se em teores considerados adequados para as gramineas forrageiras tropicais. As relações N/S e Ca/P também foram afetadas pelos periodos, independentemente das épocas de aplicação de $\mathrm{N}$, sendo encontradas maiores relações N/S no periodo de "verão" e maiores Ca/P no "inverno". 


\title{
INFLUENCE OF TIMES AND RATES OF NITROGEN FERTILIZATION IN THE SEASONAL PRODUCTION OF TWO TROPICAL GRASSES
}

\author{
Author: MICHELLE NAZARÉ XAVIER DA COSTA \\ Adviser: Prof. Dr. HERBERT BARBOSA DE MATTOS
}

\section{SUMMARY}

An experiment was carried out to determine the seasonal production of Panicum maximum cv. Mombaça and Brachiaria humidicola under different times and rates of nitrogen fertilization, conducted in parallel and independent experiments ( $I$ and II respectively), being determined the production green matter, dry matter, chemical and mineral composition of both. The seasonal production of pastures is one of the aggravating factors in the reduction of the animal production, explained through its alternation of periods of high and lower production. In those conditions becomes necessary to know qualitative and quantitative the seasonal production of these forages. Conducted in Novo Mundo farm, located in the municipal district of Brotas SP, the experiments $I$ and II was a randomized block design (with a fatorial combination $3 \times 3 \times 2)$, being appraised three rates of nitrogen $(50,100$ and $150 \mathrm{~kg} \mathrm{~N})$, at each three applications times (total in November; $1 / 2$ in November and $1 / 2$ in March and $1 / 3$ in November and $2 / 3$ in March) in the summer and winter periods, with nine repetitions. Ammonium nitrate was used $(33 \% \mathrm{~N})$ in the treatments, superphosphate $(100 \mathrm{~kg})$ and potassium chloride $(100 \mathrm{~kg})$ as basic fertlization. An interval was determined among courts of 4 weeks in the summer and 8 weeks in the winter. Test of comparison of averages (T-Student) for statistical analysis of the results.

The obtained results indicated that for both studied grasses, there was a seasonally in the production during the year. Panicum maximum cV. Mombaça and Brachiaria humidicola presented improvements in the distribution of production of dry 
matter among the times "summer" and " winter " with application of $\mathrm{N}(78 \%$ in the " summer " and $22 \%$ in the "winter "), even so for the cv. Mombaça the rates and times of application of $\mathbf{N}$ did not provide differences in the contents of crude protein, while, for Brachiaria humidicola the parceled out time of $1 / 3$ in nov. and $2 / 3$ in mar. were more appropriate, providing smaller differences in the contents among the periods. The mineral composition was another variable quite influenced by the periods. The contents of $\mathrm{N}, \mathrm{P}, \mathrm{K}$ and $\mathrm{S}$ were higher in the " summer " and for $\mathrm{Ca}$ and $\mathrm{Mg}$ the largest concentrations were obtained in the "winter ". The relationship N/S was larger in the parceled out times that in the total application in the $\mathrm{Cv}$. Mombaça while for Brachiaria humidicola, the relationship only afeccted for the periods, resulting in larger values in the "summer". The relationship Ca/P in both grasses was superior just in the "winter". 


\section{INTRODUÇÃO}

Trabalhos de pesquisa que visam otimizar a exploração dos pastos tropicais devem ter como bases um eficiente estabelecimento e manejo de forrageiras em conjunto com a adubação de pastagens. O equilibrio entre produção e qualidade da forragem é importante, para se estabelecer estratégias de utilização de pastagens mantendo alta produtividade.

No Brasil central e sudeste, cerca de $85 \%$ das produções de plantas forrageiras concentram-se no periodo quente e chuvoso (outubro a março) e $15 \%$ nas secas (abril a setembro). A produção de forragem acompanha estreitamente a distribuição anual das chuvas e temperatura, apresentando, por conseguinte, um periodo de excesso e outro de escassez de produção forrageira (Werner, 1970).

O principal problema para a exploração pecuária, em regime de pasto no Brasil Central, sem dúvida, está ligado à produção estacional das forragens tropicais. Assim sendo, a taxa de crescimento de uma pastagem e, consequentemente, a sua produção de matéria seca, são influenciadas principalmente pelas condições climáticas (luz, temperatura, umidade) e também pelas práticas adotadas (Favoretto et al., 1988).

A baixa produção de forragens durante a seca, tem sido apontada como um dos fatores que contribuem para a deficiência na produtividade dos rebanhos, sendo responsável pela queda acentuada da produção leiteira, perda de peso dos animais de corte e grande redução na capacidade de suporte dos pastos (Paulino et al., 1995). Além do efeito direto e benéfico na produção de matéria seca e na qualidade da forragem e, consequentemente, na produção animal, o emprego de fertilizantes e corretivos acaba por aumentar a disponibilidade de nutrientes para reciclagem no sistema (Monteiro e Werner,1995).

Para obtenção de alimento em quantidade e qualidade a partir de pastagens, é fundamental o reconhecimento das plantas forrageiras como culturas tão ou mais 
exigentes quanto qualquer outra, e que possuem, portanto, requerimentos específicos de temperatura, precipitação, umidade e fertilidade do solo, manejo do pastejo e etc., que isoladas ou conjuntamente, determinam a persistência, a produção e produtividade das áreas de pastagens, ou seja, sua sustentabilidade (Silva, 1995).

O objetivo deste trabalho foi avaliar a produção estacional dos capins, Panicum maximum cv. Mombaça e Brachiaria humidicola sob diferentes épocas de aplicação e doses de adubação nitrogenada determinando a produção de matéria seca, composição bromatológica e mineral para ambas forrageiras. 


\section{REVISÃO DE LITERATURA}

\section{1 origem e caracterização}

\subsubsection{Panicum maximum cv. Mombaça}

Lançado comercialmente em 1993 fruto de um longo trabalho de seleção coordenado pela EMBRAPA, o Panicum maximum cv. Mombaça (BRA-006645) foi coletado pelo ORSTOM (Institut Français de Recherche Scientifique pour le Développpement en Coopération) em Korogwe, na Tanzânia, África (Jank,1995).

Savidan et al. (1990) descreve o capim P. maximum cv. Mombaça como uma planta cespitosa com altura média de $1,65 \mathrm{~m}$. As folhas são quebradiças, com largura média de $3,0 \mathrm{~cm}$ e sem cerosidade. As lâminas apresentam poucos pêlos, duros e curtos, principalmente na face superior. As bainhas são glabras. Os colmos são levemente arroxeados. A inflorescência é uma panícula com ramificações primárias longas e secundárias longas apenas na base. As espiguetas são glabras, uniformemente distribuidas e arroxeadas em aproximadamente $1 / 3$ da superfície extema. O vertículo normalmente apresenta micropilosidade.

Segundo Jank (1995), as diferenças agronômicas encontradas entre os cultivares Tanzânia 1 e Mombaça lançados pelo CNPGC, e as testemunhas cvs. Colonião e Tobiatã foram superiores ao "Colonião" em todas as caracteristicas avaliadas, com exceção para sementes no cv. Mombaça. Foram também mais produtivos que o "Colonião", apresentaram melhor rebrota e maior percentagem de folhas. A distribuição da produção durante $O$ ano também foi melhor e semelhante entre eles e o Tobiatã. O "Mombaça", nas condições de experimento, foi $8 \%$ mais produtivo que o "Tobiatã". A menor produção de sementes do "Mombaça" não significa que seja um mau produtor, uma vez que a colheita de uma das áreas adubadas para produção no CNPGC foi de $142 \mathrm{~kg} / \mathrm{ha}$ de sementes puras, (média de sete anos), 
podendo ser ainda mais favorecida em solos mais férteis. O "Mombaça" por ser de porte maior e produção, poderá ter muito êxito em sistemas de pastejo intensivo e rotacionado.

De acordo com Santos (1997), informações sobre os capins Tanzânia e Mombaça ainda são muito escassas e a maior parte dos dados publicados é proveniente de ensaios de avaliação dos cultivares. A determinação mais cuidadosa das exigências quanto ao manejo e à fertilidade de solo é fundamental no sentido de evitar que esses cultivares sejam prejudicados devido ao uso inadequado.

\subsubsection{Brachiaria humidicola}

Segundo Dias Filho (1983), os pesquisadores Simão Neto e Serrão (1974), reportaram sua origem como sendo de "Zululand", região nordeste da província de Natal, na África do Sul. Na África, a distribuição geográfica de Brachiaria humidicola é desde o norte da Nigéria, até Angola, Tanzânia, Zimbábue, Momçabique e as áreas subtropicais de Transvaal na África do Sul (Rendle 1911, Hubbard et al. 1936, Sendulsky 1978).

No Brasil foi introduzida em 1965, através de material vegetativo de uma coleção, procedente da Universidade da Flórida, coletada na África por Oaks. Dentro do país, o material original (Brachiaria sp. UF 717) foi introduzido no lbec Research Institute-IRI, em Matão, São Paulo, onde recebeu a identificação de Brachiaria sp. IRI 409. Em outubro do mesmo ano, a $B$. humidicola foi introduzida no trópico úmido brasileiro através do antigo Instituto de Pesquisa Agropecuária do Norte - IPEAN, em Belém, mediante material vegetativo oriundo do IRI (Simão Neto e Serrão, 1974).

Dias Filho (1983) descreveu a espécie como planta perene de até um metro de comprimento e hábito decumbente; colmo subcilíndrico, glabro; nós glabros. Folha lanceolada, normalmente glabra, semicoreácea com cerca de $3 \mathrm{~mm}$ de largura, margem delgada, curtamente aculeada. Inflorescência racemosa terminal, com um a três racemos de 2 a $5 \mathrm{~cm}$ de comprimento. Espiguetas unisexuais pilosas, biflorais de aproximadamente $5 \mathrm{~mm}$ de comprimento, dispostas apenas de um lado ao longo do ráquis subalado, comprimido e glabro. Floreta perfeita de 3 a $4 \mathrm{~mm}$ de comprimento.

O capim quicuio-da-amazônia como é chamada a Brachiaria humidicola propaga-se facilmente tanto por sementes como vegetativamente (mudas e estolões). Italiano e Silva (1986) confirmaram o sucesso em Goiás, mesmo porque, nessa região, 
produzem-se sementes viáveis. Todavia, na região amazônica, a propagação vegetativa tem sido a mais comumente utilizada, em virtude das sementes produzidas serem de baixa viabilidade. Esta forrageira apresenta características altamente desejáveis tais como: elevada produtividade, rusticidade, agressividade e adaptabilidade às condições de solos ácidos e de baixa fertilidade. Ademais fornece excelente cobertura ao solo, protegendo contra a erosão, além do que a população de ervas daninhas é rara nesta pastagem. Outra importante característica e razão principal da sua grande expansão é a sua a parente tolerância ao ataque da cigarrinha.

Italiano e Silva (1986), em um trabalho realizado em Manaus, estudando a produtividade e a composição química do capim quicuio-da-amazônia em diferentes estádios de crescimento no periodo mais chuvoso do ano, determinaram que a produção de matéria seca do capim aumentou consistentemente com o avanço em idade da planta, passando de $171 \mathrm{~kg} \cdot \mathrm{ha}^{-1}$ aos 14 dias para $2.754 \mathrm{~kg}^{\mathrm{ha}} \mathrm{ha}^{-1}$ aos 56 dias de crescimento, sendo que a maior diferença de produção foi aquela verificada entre os 28 e 35 dias. Também o teor de matéria seca da gramínea aumentou com os estádios de crescimento, registrando-se valores de $13,9 \%$ aos 14 dias e $26,3 \%$ aos 56 dias.

Costa (1997) reunindo as informações existentes na literatura, sobre os rendimentos de MS de Brachiaria humidicola obtidos em diversos locais do trópico úmido sul-americano, observou (intervalos entre $810 \mathrm{~kg} . \mathrm{ha}^{-1}$ a $6.020 \mathrm{~kg} . \mathrm{ha}^{-1}$ no periodo chuvoso e $516 \mathrm{~kg} \cdot \mathrm{ha}^{-1}$ a $5.160 \mathrm{~kg} \cdot \mathrm{ha}^{-1}$ no seco) que em diferentes localidades evidenciaram-se os efeitos das condições edafoclimáticas no potencial de produção de matéria seca desta gramínea.

\subsection{Estacionalidade}

No Estado de São Paulo, como no restante do país, a permanência de animais nas pastagens é possivel durante todo o transcorrer do ano, uma vez que não há elementos climáticos rigorosos que exijam a contenção de animais em abrigos. Por outro lado, a produção estacional de pastagens se traduz pela alternância de períodos de produções altas e baixas. Nessas condições, é evidente a importância de se conhecer qualitativa e quantitativamente o ciclo estacional dos nossos principais capins. A taxa de crescimento de uma pastagem, além da nutrição, depende da estrutura e da fisiologia dos vegetais que a compõem e da interação desses dois 
fatores com as condições climáticas reinantes. Dessa maneira, quando se estuda a sua produção, é desejável que diferentes estádios de crescimento atuem a um mesmo tempo com as diversas condições climáticas que ocorrem no decorrer do ano. Essas condições são mais adequadas para o estudo de produção de pastagens onde há uma produção contínua de forragem. Os ensaios comuns de corte de plantas forrageiras removem toda a vegetação de uma só vez, havendo portanto, em qualquer instante dado, uma só condição de relvado (Pedreira, 1973).

Pedreira e Mattos (1981) avaliando a produção estacional de vinte e cinco capins em termos de produção de matéria seca e proteina bruta, determinaram que a produção anual de matéria seca foi acentuadamente estacional, com média de todos os capins correspondente a $11 \%$ no "inverno" em relação ạo "verão". Entre as maiores produções obtidas de matéria seca e proteína bruta durante o "verão" estavam os capins Brachiaria decumbens cv. Australiano (1.450g. $\mathrm{m}^{-2}$ e $94 \mathrm{~g} \cdot \mathrm{kg}^{-1}$ ) e Panicum maximum var. Trichoglume (1.290g. $\mathrm{m}^{-2}$ e $\left.110 \mathrm{~g} \cdot \mathrm{kg}^{-1}\right)$.

Teixeira Neto e Nery (1983), em trabalho realizado na ilha de Marajó - PA, avaliando a produtividade estacional de pastagem nativa e Brachiaria humidicola, obteve maiores ofertas de forragem no final da estação chuvosa, ocorrendo o inverso ao fim do periodo seco. Como regra, a produção Brachiaria humidicola superou a da pastagem nativa em mais de duas vezes, comprovando a excelente adaptação às condições durante a estação chuvosa, quando o lençol freático quase aflora, não afetando a produtividade de B. humidicola. Em geral, ambos os pastos apresentaram produções de forragem crescentes até os 84 dias de idade.

Segundo Abramides et al. (1983), em experimento conduzido no Instituto de Zootecnia de Nova Odessa - SP, estudando variações estacionais da taxa de acúmulo diário de matéria seca (TADMS), dos teores de proteína bruta (PB) da matéria seca na Brachiaria humidicola durante o ano, observaram que houve grande estacionalidade da TADMS, variando de 8 a $87 \mathrm{~kg} \cdot \mathrm{ha}^{-1}$. dia $^{-1}$ sendo esta superior, no periodo das águas.

Valentim e Moreira (1994), objetivando fornecer informações aos extensionistas e produtores sobre as características, potencialidades e limitações do Mombaça para formação de pastagens no Acre, determinaram que, do total da produção anual de forragem (1900g. $\mathrm{m}^{-2}$.ano-1) $60 \%$ ocorreu no período chuvoso e $40 \%$ no período seco, estando de acordo com os resultados obtidos neste trabalho. 
O clima possui efeito bastante forte sobre a distribuição e a produção das plantas forrageiras. O Brasil é um pais tropical que possui a maior proporção de sua área situada entre as linhas do Equador e do Trópico de Capricómio, $\left(0^{\circ}\right.$ e $25^{\circ} \mathrm{S}$ de latitude) região do globo caracterizada por temperaturas médias anuais elevadas, e portanto, bastante favorável à presença de Panicum sp.. Nos meses de outono e inverno é comum, em algumas regiōes do país, a ocorrência de temperaturas mínimas ligeiramente inferiores a $15^{\circ} \mathrm{C}$, particularmente para aquelas regiōes situadas mais ao Sul e/ou de altitude mais elevada em relação ao nivel do mar, sendo este um dos principais fatores responsáveis pela estacionalidade de produção forrageira, mas que não limita de maneira alguma a presença e a produção de Panicum sp. nestas áreas (Silva, 1995).

De acordo com Corsi e Santos (1995), somente cerca de 10\% da produção anual é obtida durante o "inverno", indicando que o capim colonião é planta de "verão", devendo, por isso, ser incluida no sistema de manejo para explorações intensivas nesta época do ano. Quando explorada durante o "verão", esta planta forrageira pode contribuir para a liberação de área considerável da propriedade, que seria utilizada para a produção de alimento para o "inverno". Se as lotaçōes das pastagens de colonião que estão ao redor de 2,0UA/ha puderem ser elevadas, pelo menos, para 4,0UA/ha, teremos liberação de cerca de $50 \%$ da área ocupada atualmente com pastagem para produção de alimento para o "inverno". A possibilidade de aproveitar o capim colonião para confecção de silagem amplia a flexibilidade de uso desta gramínea no "verão" e contribui para reduzir os problemas de escassez de alimento no "inverno". A estacionalidade de produção do Panicum parece ser característica limitante se analisada, sob aspecto de porcentagem de produção da forragem durante o "invemo" em relação à produção anual ou total.

A análise da estacionalidade de produção baseada no percentual de produção de inverno em relação à produção anual dá margem para interpretação distorcida dos resultados de pesquisa. Assim, Jank et al. (1994) apontaram que a melhor distribuição de produção de forragem entre o verão e o invemo não foi encontrada nas variedades mais produtivas. K 122 e T 56, em áreas adubadas, destacaram-se pela melhor distribuição da produção, uma vez que produziram durante o inverno 20,6 e 17,5\%, respectivamente, da produção anual. Aparentemente essas variedades seriam muito superiores à variedade Tanzânia 1 e Mombaça, uma vez que estas produziram, sob 
adubação, somente $11 \%$ durante o inverno. Entretanto, analisando a quantidade de forragem produzida durante o invemo, observa-se que as variedades Tanzânia 1 e Mombaça produziram 2,55 vezes mais do que a variedade $K 122$ e T 56, produção de matéria seca suficiente para aumentar significativamente a lotação das pastagens. Esses resultados demonstram que a produção de matéria seca no inverno, e não o percentual de produção em relação à produção anual, reflete melhor potencial da planta forrageira para atender as necessidades e alimentos durante 0 inverno.

Corsi e Santos (1995) nos alertam sobre a estacionalidade de produção de que os valores devem ser analisados de maneira mais abrangente, envolvendo o sistema de produção. Análises baseadas na taxa de crescimento da planta forrageira definem melhor a lotação animal, esclarecendo as possibilidades do emprego de produções de verão e de inverno. Estudos que consideram a porcentagem de produção da forragem durante o inverno tendem a confundir, dificultar os progressos da seleção e passam a idéia de que a solução para o "inverno" é a escolha de espécies que tenham maior equilíbrio entre a produção de "verão" e a de "inverno". Na verdade, a escolha da espécie entre a produção da forrageira depende mais do sistema de produção do que o de equilíbrio, tão procurado, entre "verão" e "inverno".

Souza Filho et al. (1992) estudando comparativamente, as variações na produção de matéria seca e composição química de pastagens nativas (pertencentes aos gêneros Axonopus, Andropogon, Eragrostis, Trachypogon, Paspalum e Aristida) de área de Cerrado melhoradas de Brachiaria humidicola, cultivadas em quatro épocas (jan.-mar.; abr.-jun.; jul.-set. e out.-dez.) e três idades de corte (30, 60 e 90 dias), concluíram que a Brachiaria humidicola possui potencial forrageiro superior ao das pastagens nativas, apenas em função da maior capacidade de produção de forragem. O teor de PB apenas na época out.-dez., foi igual estatisticamente nas tres idades de corte, tendendo a decrescer com o aumento das mesmas, sendo que em nenhuma das idades o valor mínimo de PB (80g. $\mathrm{kg}^{-1}$ na MS), para bovinos de corte foi atingido.

Cardoso et al. (1997), determinando o conteúdo nutricional de Brachiaria humidicola em relação a proteína bruta relacionada com as estações chuvosa e seca na llha de Marajó-PA, obtiveram resultados de que o conteúdo de PB foi baixo, tanto na estação seca $\left(35 \mathrm{~g} \cdot \mathrm{kg}^{-1}\right)$, quanto na chuvosa $\left(48 \mathrm{~g} \cdot \mathrm{kg}^{-1}\right)$. Os níveis foram inferiores do que o requerido para o gado bubalino e bovino $\left(>70 \mathrm{~g} \cdot \mathrm{kg}^{-1}\right)$. 0 microclima pareceu influenciar o conteúdo de $\mathrm{PB}$, haja visto que concentrações elevadas de $\mathrm{PB}$ para 
Brachiaria humidicola tem sido relatadas no trópico úmido, onde a quantidade de precipitação pluvial durante a estação seca foi acima de $100 \mathrm{~mm}$.

\subsection{Adubação}

As doses de adubação nitrogenada em pastagens tropicais variam grandemente, dependendo das condições de solo e clima, e do nível tecnológico da exploração. Em explorações intensivas tem sido observadas respostas positivas a até $800 \mathrm{~kg} / \mathrm{h} a / a n o$ de $\mathrm{N}$, na maioria dos casos, entretanto, as quantidades econômicas de aplicação de $\mathrm{N}$ são bem mais modestas. As aplicações de $\mathrm{N}$ são também indicadas nos períodos de rebrota das pastagens, para aumentar a sua velocidade de crescimento e o percentual de proteina bruta (Rossiello e Fernandes, 1986).

Atualmente a técnica de adubação de pastagens tem-se tornado mais aceita e utilizada, como demonstrado pelo grande número de reportagens e entrevistas publicadas recentemente sobre o assunto. No entanto, a filosofia segundo a qual esta tecnologia tem sido utilizada considera, em sua grande maioria, apenas a elevação do níveis de fósforo no solo, como se fosse esse o único elemento limitante para a produção das pastagens. É importante ressaltar com isso que adubação de pastagens envolve, acima de tudo, conceitos de nutrição mineral de plantas, segundo os quais o aumento em resposta a nutrientes aplicados isoladamente pode existir mas será, de pequena grandeza, uma vez que outros nutrientes passarão a ser os limitantes, demonstrando assim a necessidade de se adequar o sistema solo-planta-animal como um todo à finalidade de exploração e não a consideração de componentes do sistema isoladamente (Silva, 1995).

A manutenção dos índices de produtividade requer adequada reposição de nutrientes, através da adubação de manutenção. É necessário o conhecimento sobre o comportamento de novos cultivares de lançamento mais recente, com relação às exigências e características produtivas (Paulino et al., 1998)

Vicent-Chandler (1974), trabalhando em Porto Rico, relatou que as gramíneas forrageiras mais responsivas (Pennisetum purpureum, Panicum maximum, etc) apresentam incrementos na produção de matéria seca, com doses de até aproximadamente $1.800 \mathrm{~kg}$.ha.ano. 
De maneira geral, a resposta dos capins à adubação nitrogenada é crescente até doses elevadíssimas (1.600kg/N/ha/ano), entretanto, a eficiência da utilização do nitrogênio aplicado cai à medida que se ultrapassa um determinado limite $( \pm 300$ $400 \mathrm{~kg} / \mathrm{N} / \mathrm{ha} / \mathrm{ano}$ ). Existem porém, os capins que respondem até às doses mais altas do elemento, como por exemplo o napier, colonião e o angola, etc. e aqueles que devido a um crescimento fisiológico mais lento, como por exemplo o gordura, só respondem, a um aumento de produção de forragem, até doses moderadas (200-250kg de N/ha/ano) (Werner, 1983).

Muitos trabalhos com gramíneas tropicais indicam que os máximos rendimentos são obtidos com o uso de 400 a $500 \mathrm{~kg} \cdot \mathrm{ha}^{-1}$ de N. Kohmann e Jacques, (1979), trabalhando em Uganda com quatro gramineas tropicais, entre elas Panicum maximum e Setaria anceps testando o efeito de pesadas aplicações de nitrogênio, concluiu que todas as gramíneas responderam fortemente ao nitrogênio até $448 \mathrm{~kg}^{\mathrm{h}} \mathrm{ha}^{-1}$, com pouco acréscimo de produção em até $896 \mathrm{~kg} \cdot \mathrm{ha}^{-1}$. Acima desta dose houve um declínio no rendimento de matéria seca. Os rendimentos de MS de Panicum maximum foram de 9.700kg.ha-1, 25.600kg.ha-1 e 24.900kg.ha-1, respectivamente, com 448kg.ha-1 e $896 \mathrm{~kg} . \mathrm{ha}^{-1}$. Para Setaria anceps os rendimentos foram de $7.600 \mathrm{~kg} . \mathrm{ha}^{-1}, 19.300 \mathrm{~kg} \cdot \mathrm{ha}^{-1} \mathrm{e}$ 22.000kg.ha- ${ }^{-1}$, nas mesmas doses de N.

Davison et al (1985), avaliando um experimento conduzido com vacas de leite durante tres anos em Queensland, Australia, determinaram os efeitos das taxas de lotação (3,5 vacas/ha) e fertilizante nitrogenado aplicado (200 e 400 kg N.ha ${ }^{-1}$.ano-1 de nitrato de amônio), sobre o rendimento e composição da pastagem, seleção da dieta pelas vacas e fertilidade do solo de pastagens de Gatton panic (Panicum maximum cv. Gatton). Os resultados do estudo mostraram que pastagens de Gatton panic adubadas com nitrogênio podem suportar taxas de lotação mais elevadas, do que em consórcios de pastagens de leguminosa-gramínea, e que sua composição botânica permaneceu estável acima de 3,0 vacas/ha se aplicado $400 \mathrm{~kg} \mathrm{~N} \cdot \mathrm{ha}^{-1} \cdot \mathrm{ano}^{-1}$. As pastagens consideradas neste experimento, consistentemente forneceram elevadas doses de matéria seca e oferta de folhas entre o verão e o final do outono. Enquanto que a oferta de pastagem, na primavera, foi a maior limitação para a produção animal e outras fontes de alimento e irrigação tiveram que ser requeridas para conseguir manter a produção animal. As aplicações de $400 \mathrm{~kg} \mathrm{~N} \cdot \mathrm{ha}^{-1} \cdot \mathrm{ano}^{-1}$ aumentaram a oferta de 
pastagem verde, em todas as estações produzindo um alto conteúdo de proteína bruta e maior quantidade de folha resultando em uma elevada qualidade da dieta.

Davison et al. (1987), determinaram os efeitos de doses ( 200 e $400 \mathrm{~kg} \mathrm{~N} . \mathrm{ha}^{-1}$. $a n o^{-1}$ )e a freqüência (intervalos de tres aplicações: 3,6 e 12 semanas) de nitrogênio aplicado em pastagens de Gatton panic (Panicum maximum cv. Gatton) e relataram que não houve nenhuma diferença significativa sobre o rendimento da pastagem ofertada, proteína bruta e conteúdo mineral, entretanto, a dose mais elevada do fertilizante nitrogenado produziu pequenos incrementos no rendimento da pastagem ofertada, proteína bruta e conteúdo mineral na dieta e reduções na concentração de fósforo, enquanto que as concentrações de cálcio e magnésio aumentaram. Os pesquisadores mostraram que, pastagens adubadas com doses de 200 a $400 \mathrm{~kg}$ N.ha ${ }^{1}$.ano-1 não trazem nenhuma vantagem na aplicação parcelada maior do que tres vezes durante a estação de crescimento.

Segundo Favoretto et al. (1988), aumentos na produção de matéria seca por corte de 46 e $78 \%$, mediante a aplicação de 50 e 100kg de N/ha, respectivamente, revelam que apesar da diferença considerável entre esses valores, estatisticamente são iguais, sendo esse mesmo comportamento observado também quando se comparou a taxa de crescimento diário e capacidade de suporte estimada também trabalhando com capim colonião, obtendo aumentos significativamente superiores na produção de matéria seca da ordem de 126 e 156\%, mediante utilização de 75 e $100 \mathrm{~kg}$ de N/ha. As aplicações de 50 e 100kg de N/ha elevaram as taxas de crescimento de 68,16 a $83,71 \mathrm{~kg}$ de MS/ha/dia, respectivamente, concluindo que o incremento na produção de matéria seca mediante o uso de nitrogênio resultou no aumento da taxa de crescimento das plantas e também da capacidade de suporte estimada.

Para Mabe et al. (1988), a pastagem adubada com nitrogênio propiciou melhor cobertura do solo, com percentuais de capim colonião sempre superiores a $50 \%$ e baixas proporções de invasoras e de solo nu, quando comparada as pastagens de capim colonião e consorciado com soja perene.

Trabalhos realizados com colonião mostram crescente redução de produção de matéria seca através dos anos, devido à queda de fertilidade do solo. Ghisi et al (1989), constataram o efeito, ao longo do prazo de tres anos em Belém do Pará

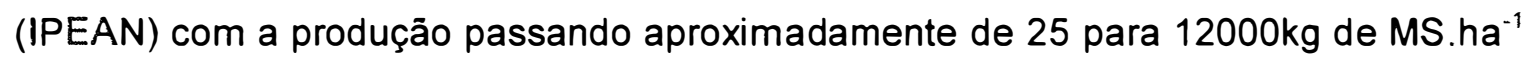
ano ${ }^{-1}$. 
A aplicação de nitrogênio (150kg/ha/ano) em uma área com capim-colonião estabelecida foi realizada por (Monteiro, 1995), que obteve significativo aumento na produção de matéria seca durante o ano. Dos resultados apresentados, pode-se verificar que, na média dos cinco periodos de crescimento avaliados durante todo o ano, a taxa de crescimento do capim aumentou de 14,36 para 31,23kgMS/ha/dia, em conseqüência da adubação nitrogenada. A quantidade de $\mathrm{kg}$ matéria seca do capim por kg de nitrogênio aplicado foi de 27,9.

Wemer (1970), na busca de obter maior suprimento de forragem para época seca, avaliou nove épocas de aplicação de adubação nitrogenada (100kg de N.ha-1. ano ). Baseando-se em resultados de tres anos relatou diferenças significativas na produção anual de matéria seca, entre as áreas adubadas e as não adubadas com nitrogênio, não encontrando variações significativas quanto as épocas de adubação. $A$ eficiência média de conversão esteve entre 27,7 e 3,2kg M.S./kg N, para as épocas avaliadas. Todavia, quando considerada proporção da produção de matéria seca no período das "secas" em relação ao total anual, obteve 21,0\% para adubação em março de cada ano, em contraposição aos 7,6 a $9,0 \%$ verificados para as adubações de novembro e janeiro, respectivamente.

A adubação nitrogenada pode resultar também em uma melhor distribuição anual da produção de matéria seca, entre os periodos de "inverno" e "verão", podendo elevar a produção total de proteína durante o período da "seca". (Monteiro e Werner 1977).

Addison et al. (1985) avaliaram durante quatro anos o efeito de tres doses de $\mathrm{N}$ $\left(22,5 ; 45\right.$ e $\left.90 \mathrm{~kg} \mathrm{ha}^{-1}\right)$ sobre produção animal em pastagens de green panic (Panicum maximum cv. Tichoglume), na Austrália, aplicados anualmente em uma pastagem de cinco anos. As pastagens possuiam uma taxa de lotação de 2,5 novilhas/ha a partir de setembro até o final de fevereiro (primavera/verão) de cada ano e a forragem residual deixada a cada estação de pastejo era cortada para feno e oferecida "ad libitum", na próxima primavera ou deixada nos piquetes. A produção das pastagens responderam de forma linear ao aumento das doses de nitrogênio e foram maior em matéria seca em relação àquelas que não foram pastejadas, a densidade de raizes não foi influenciado pelas doses de nitrogênio, mas aumentou no corte para feno. Green panic continua como uma das espécies mais importantes que possuem resposta a elevadas doses de nitrogênio. Seus resultados demonstraram que em condições anuais, 90kg 
de N.ha' ${ }^{-1}$ são requeridas para manter uma elevada proporção de green panic nas pastagens cujo pastejo ocorre na primavera e no verão.

Andrade et al. (1991) em experimento conduzido no Instituto de Zootecnia de Nova Odessa-SP, durante dois anos agricolas, comparando tres capins da espécie Panicum maximum Jacq. (Colonião, Tobiatã e K-187 B) sob duas doses de adubo nitrogenado (80 e 240 kg.ha ${ }^{-1}$. ano $^{-1}$ ) quanto à produção de matéria seca e proteína bruta, determinaram que, não houve diferença significativa em relação à essas variáveis entre os capins estudados, apesar da adubação nitrogenada ter afetado positivamente a produção de matéria seca e proteína bruta tanto no "verão", quanto no "inverno" e anual. A participação percentual de produção de matéria seca no "inverno" em relação ‘a produção de matéria seca anual foi maior, para a dose de nitrogênio menor. Enquanto que, para a participação de proteína bruta no "inverno "em relação `a produção de proteina bruta anual não sofreu alteração com as doses de nitrogênio aplicado.

A produção de carne em pastagem de capim-colonião formada há 11 anos e recebendo diferentes doses de nitrogênio $\left(0,100\right.$ e $200 \mathrm{~kg} \mathrm{ha}^{-1}$.ano ${ }^{-1}$ ), foi avaliada na região de Araçatuba (SP), empregando bovinos Nelore e aplicando fósforo e enxofre em todos os pastos. Verificou que tanto o número de novilhos como o ganho de peso dos animais por hectare foi mais que duplicado, com elevação das doses de nitrogênio. Em termos de ganho de peso vivo pelo animal vivo por quilograma de nitrogênio aplicado obtiveram 1,86 para o nivel de 100 e 1,98 para a dose de 200. O autor ainda acrescenta que a aplicação do adubo nitrogenado no final das "águas" trouxe importante contribuição à produção animal por hectare naquela pastagem. (Monteiro, 1995)

As gramineas e leguminosas dependem do nitrogênio para o seu desenvolvimento, como a necessidade do mesmo para a produção de pastagens é grande, geralmente são obtidas respostas à aplicação desse elemento. Considerando às grandes perdas deste nutriente por lixiviação, recomenda-se o parcelamento das quantidades anuais em um maior número de aplicações, para um maior aproveitamento da planta. Basicamente há duas recomendações quanto à época do ano em que a adubação nitrogenada seria melhor aproveitada em termos de produção. No fim das águas, visando prolongar o pastejo e a maior produção de forragens na 
seca e durante as águas, visando o máximo de aproveitamento da estação de maior produção, inclusive para armazenamento de forragens (Guimarães et al., 1980)

A aplicação de adubos nitrogenados nas pastagens deve ser feita em cobertura (sobre toda a superficie do pasto), manual ou mecanicamente, após o rebaixamento da forragem, por meios mecânicos (roçadeira, cegadeira) ou de preferência, com a boca do animal, usando-se uma lotação pesada de animais na área a ser adubada. Recomenda-se aplicar a dose média ou a leve do adubo nitrogenado, no final do periodo das chuvas (março, para as condições do estado de São Paulo), que proporciona um acentuado aumento de produção de forragem para o periodo das secas e uma rebrota mais precoce no inicio da primavera. Quanto à dosagem intensa recomenda-se usá-la parceladamente aplicando-se 1/3 em dezembro-janeiro e 2/3 em março entre 100 e $250 \mathrm{~kg}$ de N.ha ${ }^{-1}$.ano ${ }^{-1}$. (Wemer, 1983).

A prática do parcelamento da adubação nitrogenada, tem o objetivo de aumentar a eficiência de utilização do adubo nitrogenado por parte da planta e diminuir as perdas por lixiviação. Essa eficiência de utilização do adubo nitrogenado também depende do intervalo entre cortes, demostrando que, as quantidades de recuperação de $\mathrm{N}$ são de aproximadamente $40-50 \%$ ou de $60-70 \%$ quando o intervalo de corte é de 40 e 60 dias, respectivamente. Corsi e Nússio (1992), apontaram que a recuperação do nitrogênio é melhorada quando a planta é capaz de aumentar o perfilhamento e o crescimento, em expansão, das folhas e dos perfilhos.

Monteiro (1995) cita que a recomendação para aplicação em pastagens de Panicum maximum varia de 50 a $300 \mathrm{~kg} / \mathrm{ha} / \mathrm{ano}$. A dose mais baixa tem sido considerada como mínima para evitar a degradação dessa forrageira na pastagem. Doses mais elevadas que a mínima são aconselhadas para incrementos na produtividade da pastagem (e por conseqüência do animal) e para explorações mais intensivas dessas pastagens, salientando que há necessidade de parcelamento dessa adubação.

Aguiar (1998), recomenda adubação nitrogenada quando houver equilibrio entre nutrientes e na época das chuvas, parcelando a adubação com $\mathrm{N}$ para aumentar a eficiência de utilização por parte da planta. A aplicação de $\mathrm{N}$ deve ser feita logo após a saída dos animais do pasto, pois os perfilhos dos capins tropicais são produzidos quase que totalmente na primeira semana após pastejo. Se a adubação é feita nesta época, ocorrerá aumento na produção de forragem a partir do aumento no número e 
peso de perfilhos. Por outro lado, se adubação for realizada apenas após a primeira semana após o pastejo, a produção só aumentará a partir do aumento no peso de perfilhos já existentes.

Correa et al., (1998) reportam que a resposta das forrageiras tropicais a altas doses de nitrogênio $(\mathrm{N})$, tem sido variável com a espécie forrageira. Quanto ao periodo de utilização dessas, a maioria dos trabalhos mostram que cortes menos freqüentes proporcionam maiores produções. Todavia doses elevadas de $\mathrm{N}$ que aceleram 0 desenvolvimento das plantas, podem proporcionar maior freqüência de cortes e/ou ciclos de pastejo. Ainda, segundo Correa et al. (1998) verificando o efeito de duas doses de adubação nitrogenada (200 e 400kg de N/ha) parcelados de acordo com as freqüências de corte, realizados nas "águas" em periodo de 180 dias aproximadamente, sobre a produção de matéria seca de doze gramineas forrageiras tropicais, entre elas (Brachiaria decumbens, B. brizantha cv. Marandu, e Panicum maximum cv. Mombaça), obtiveram resultados que mostram o efeito positivo das doses de nitrogênio na produção de matéria seca, a qual foi variável com a espécie forrageira. Embora tenha diminuido acentuadamente a produção por corte em função do aumento da freqüência, o mesmo não ocorreu com a produção total no periodo, que foi em parte compensada pelo número de colheitas. Houve diferença na produtividade das gramineas com variação em função da dose de nitrogênio.

Em trabalho conduzido por Soares e et al. (1998), na EMBRAPA- CNPGC em quatro épocas (julho/96, outubro/96, janeiro/97 e março/97), num sistema de pastejo rotacionado de capim-elefante (Pennisetum purpureum Schum.) utilizando adubações nitrogenadas (300 e $\left.700 \mathrm{~kg} \cdot \mathrm{ha}^{-1}\right)$ e potássicas $\left(200 \mathrm{~kg} \cdot \mathrm{ha}^{-1}\right)$ parceladas em tres aplicações, no início, meio e final do periodo chuvoso, com o objetivo de avaliar a disponibilidade e composição química, verificaram que a disponibilidade de matéria seca não foi afetada pelas doses de nitrogênio, contudo observou-se o efeito de épocas, cujos valores variaram de 472,7 a $2.354,8 \mathrm{~kg} \mathrm{ha}^{-1}$, entre julho e março, havendo um aumento de produção no decorrer dos meses determinando ser a dose de $300 \mathrm{~kg} \cdot \mathrm{ha}^{-1}$ a mais adequada para a exploração do capim-elefante sob pastejo. 


\section{MATERIAL E MÉTODOS}

\subsection{Localização do experimento}

O experimento foi conduzido na Fazenda Mundo Novo, pertencente a empresa Manah Agropastoril situada no municipio de Brotas, região central do Estado de São Paulo, durante o periodo de 18/08/1997 a 12/11/1998. Cada experimento ocupou $2700 \mathrm{~m}^{2}$ de pastagens exclusivas de Panicum maximum cv. Mombaça e Brachiaria humidicola. As coordenadas geográficas da propriedade são $22^{\circ} 10^{\prime} \mathrm{S}$ de latitude e $48^{\circ} 02^{\prime} \mathrm{W}$ de longitude. A topografia do local é levemente ondulada e a altitude local é de $700 \mathrm{~m}$ acima do nivel do mar.

\subsection{Clima}

O clima da região, conforme a classificação de Köppen corresponde a Cwa, ou seja, com inverno frio e seco e verão quente e chuvoso, sendo a estação seca ocorrendo entre os meses de abril a setembro (BRASIL, MINISTÉRIO DA AGRICULTURA, 1979). As temperaturas máximas e minimas registradas na área, durante o periodo experimental foram $39,0^{\circ} \mathrm{C}$ e $9,6^{\circ} \mathrm{C}$ em janeiro e junho, respectivamente.

A precipitação pluvial anual para o ano de 1998 foi de $1137 \mathrm{~mm}$, distribuídos pelos meses de dezembro, janeiro, fevereiro e março com maiores precipitações, sendo julho o mês mais seco apresentando $0 \mathrm{~mm}$ de precipitação.

A precipitação pluvial do período experimental foi medida através de pluviômetro instalado na propriedade e os resultados encontram-se na Figura 1. 


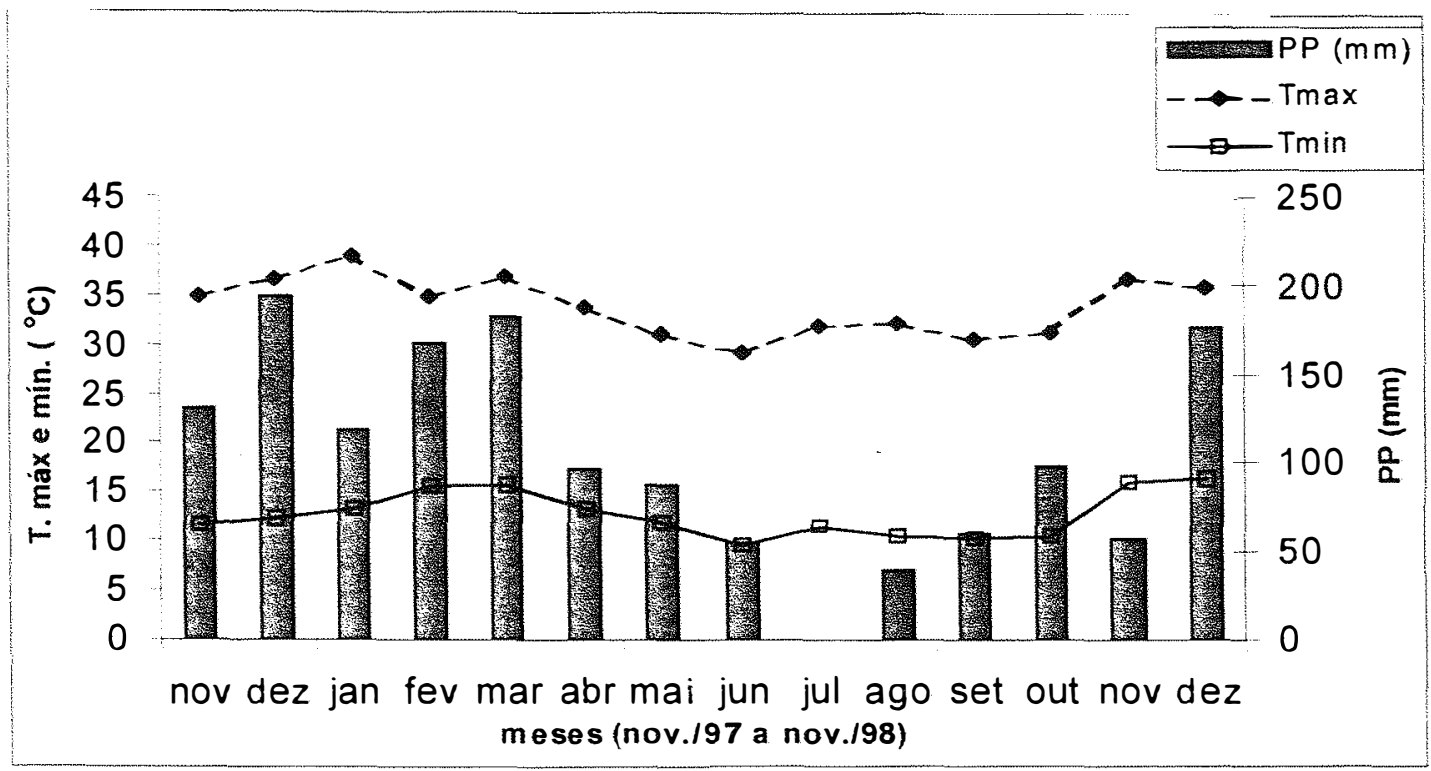

Figura 1. Precipitação pluvial, temperaturas máxima e mínima ocorridas no período experimental.

\subsection{Solo}

O solo onde foram conduzidos os experimentos é classificado como Latossolo Vermelho Escuro fase arenosa. Foram realizadas amostragens de solo na profundidade de $0-20 \mathrm{~cm}$. Sendo os resultados análise de terra da amostragem apresentados na Tabela 1.

Tabela 1. Resultados da análise química de terra da área experimental (profundidade:

0 a $20 \mathrm{~cm})^{(1)}$.

\begin{tabular}{l|l|l|l|l|l|l|l|l|l|l}
\hline & Pres & $\begin{array}{l}M . O \\
(\%)\end{array}$ & $\begin{array}{l}p H \\
\mathrm{CaCl}_{2}\end{array}$ & $K$ & $\mathrm{Ca}$ & $\mathrm{Mg}$ & $\mathrm{H+Al}$ & $\mathrm{S}$ & $\mathrm{T}$ & $\mathrm{V} \%$ \\
\hline $\begin{array}{l}\text { Panicum } \\
\text { Brachiaria }\end{array}$ & 6,2 & 2,1 & 5,18 & 0,10 & 1,09 & 0,68 & 2,25 & 1,90 & 4,10 & 45,10 \\
\cline { 2 - 10 } & 5,9 & 2,7 & 3,95 & 0,08 & 0,39 & 0,13 & 4,35 & 0,60 & 4,95 & 11,65 \\
\hline
\end{tabular}

(1)Análise realizada no Laboratório de Nutrição Mineral de Plantas, Depto. de Quimica da Escola Superior Luiz de Queiroz - ESALQ/USP, Piracicaba.

\subsection{Instalação dos experimentos}

O experimento iniciou-se em 18/08/1997, quando dentro dos piquetes foram delimitadas as áreas para execução dos experimentos. Estas áreas foram submetidas a um rebaixamento, através de carga animal, o que permitiu uma uniformização aproximadamente de $15-20 \mathrm{~cm}$ da superfície do solo. 
Cada área experimental media cerca de $30 \mathrm{~m} \times 90 \mathrm{~m}$ onde foram realizadas divisões em parcelas dos experimentos I e II em 22/09 e 15/10/1997, respectivamente, conforme indicado na Figura 2. As parcelas mediam $3,0 m \times 6,0 m$ tendo como área útil $1,0 \mathrm{~m} \times 4,0 \mathrm{~m}\left(4,00 \mathrm{~m}^{2}\right)$, as mesmas foram marcadas com plaquetas plásticas amarradas as estacas a fim de facilitar a sua localização no momento da aplicação de cada tratamento e posterior colheita das parcelas.

Em 11/11/1997 os experimentos foram adubados, recebendo o correspondente por 0,29 ha (total das duas áreas experimentais) $100 \mathrm{~kg}$ de $\mathrm{K}_{2} \mathrm{O}$ na forma de cloreto de potássio e 100kg de $\mathrm{P}_{2} \mathrm{O}_{5}$ na forma de super fosfato simples juntamente com a aplicação dos tratamentos. A fonte nitrogenada utilizada na aplicação dos tratamentos foi o nitrato de amônio.

As últimas adubações realizadas nos piquetes de Panicum maximum cv. Mombaça foram apenas na época do plantio (26/10/1995) com FOSMAG 511 M6 (cerca de $300 \mathrm{~kg} \mathrm{ha}^{-1}$ ) e Brachiaria humidicola com FOSMAG 505 (250kg.ha-1 meados de 1987/88).

De acordo com os procedimentos descritos por Pedreira (1973), os experimentos de corte contaram com repetições no tempo, para que num dado instante, houvesse diferentes estádios de crescimento.

O delineamento experimental adotado foi de blocos ao acaso, num esquema fatorial $3 \times 3$ tendo como um fator de resposta o capim (Panicum maximum cv. Mombaça e Brachiaria humidicola), com 9 tratamentos e 9 repetições para ambos, totalizando 81 parcelas de cada espécie. Dentro de cada bloco ( $A, B$ e $C$ ) cada tratamento se repetia tres vezes, o que constituía-se as repetições no tempo, denominadas de séries.

Com a defasagem de dez dias, cada série correspondeu a dez, vinte e trinta dias de crescimento. Estas séries foram cortadas, mediante a intervalos de corte estipulados descritos conforme a Tabela 2.

Os tratamentos consistiam de épocas de aplicação e doses de nitrogênio:

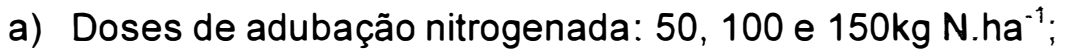

b) Época de aplicação dessas doses: aplicação total em novembro, 1/3 em novembro e 2/3 em março e 1/2 e em novembro e 1/2 em março. 

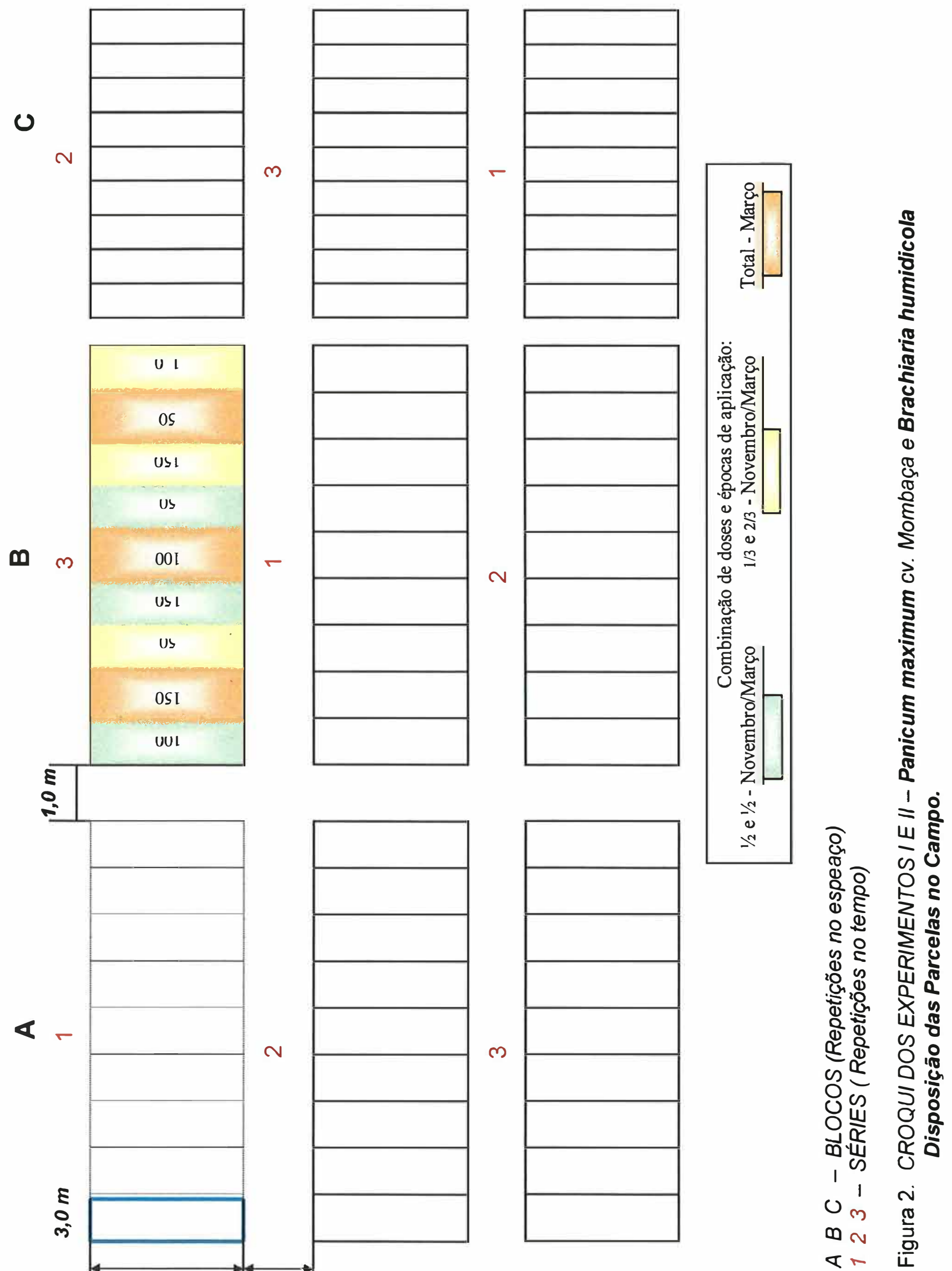
(a)

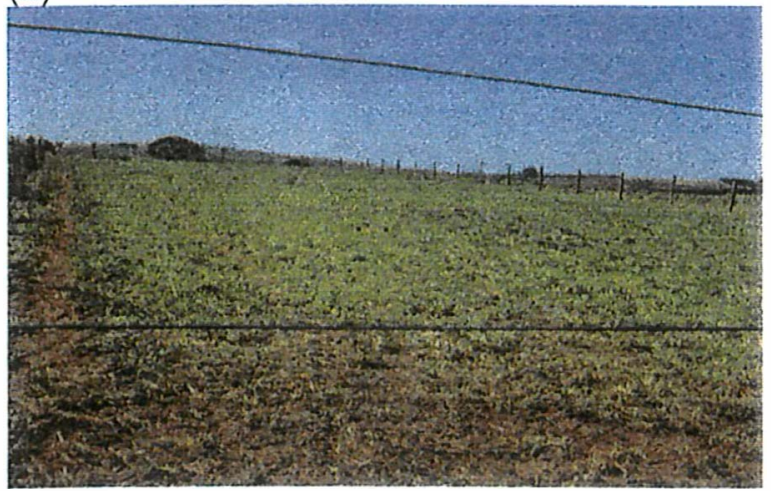

(b)

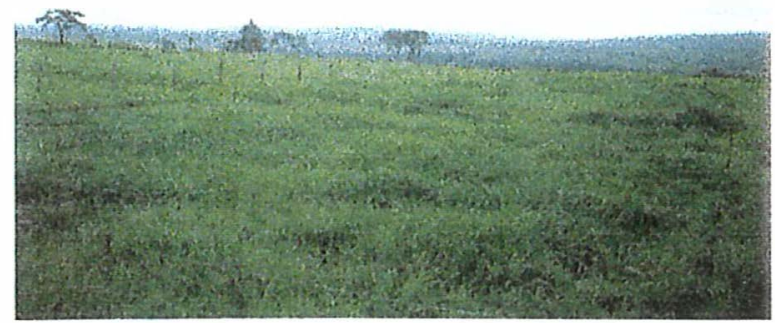

(c)

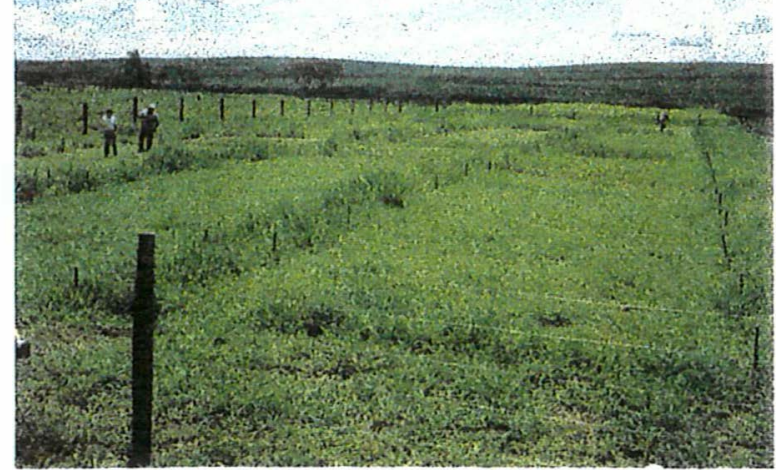

Figura 3. Visão geral da área experimental de Panicum maximum cv. Mombaça no isolamento da área (a), após aplicação dos tratamentos (b) e término de corte das parcelas (c). (a)

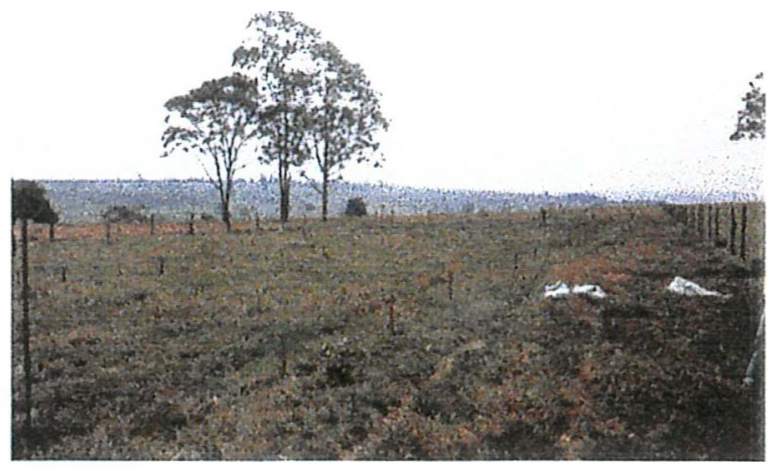

(b)

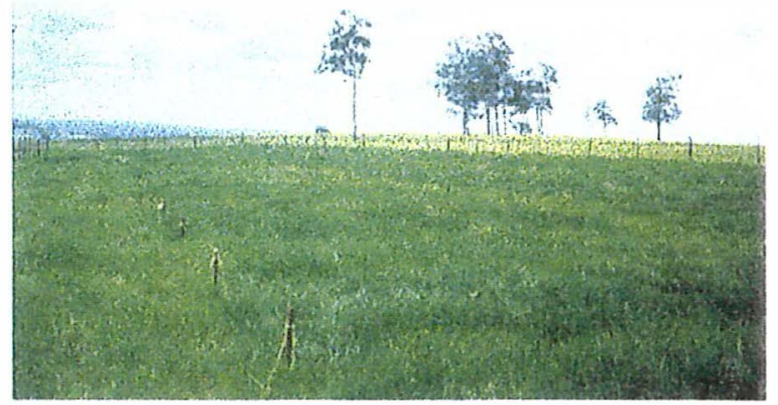

(c)

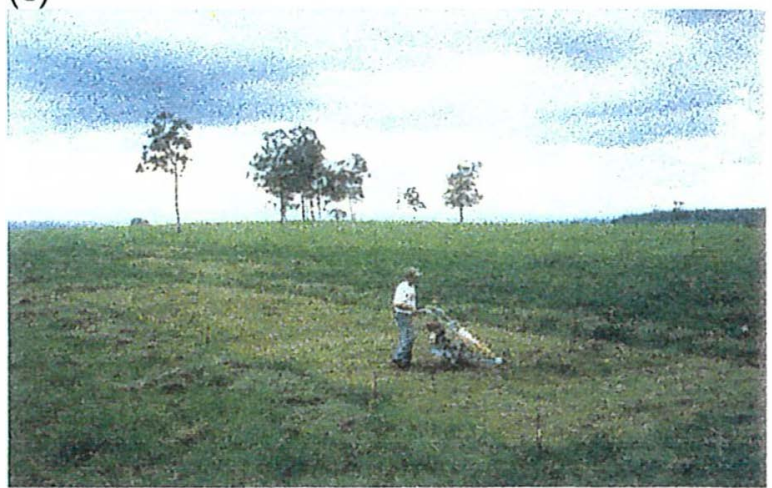

Figura 4. Visão geral da área experimental de Brachiaria humidicola no isolamento da área e identificação das parcelas (a), após aplicação dos tratamentos (b) e término de corte das parcelas (c). 


\subsection{Colheita das parcelas}

Em 11/11/1997 com a aplicação das doses de nitrogênio, após dez dias, iniciou-se a colheita das parcelas em 21/11/1997, tendo a mesma encerrando em 12/11/1998, conforme demonstrado na Tabela 2 e Figura 5.

Tabela 2. Divisão dos anos estudados em "Verão" e "Inverno", datas de corte, números de cortes e intervalos em dias referentes aos experimentos de Panicum maximum cv. Mombaça e Brachiaria humidicola.

\begin{tabular}{|c|c|c|c|c|c|c|}
\hline Ano & Periodo & Série & $\begin{array}{l}\text { Início do } \\
\text { Periodo }\end{array}$ & Data dos Cortes & $\begin{array}{l}N^{0} d e \\
\text { cortes }\end{array}$ & $\begin{array}{c}\text { Intervalos } \\
\text { em dias }\end{array}$ \\
\hline \multirow{6}{*}{$1997 / 98$} & \multirow{3}{*}{ "Verão" } & 1 & $21 / 11$ & $19 / 12-16 / 01-13 / 02-13 / 03$ & 4 & 112 \\
\hline & & 2 & $01 / 12$ & $29 / 12-26 / 01-23 / 02-23 / 03$ & 4 & 112 \\
\hline & & 3 & $11 / 12$ & $08 / 01-05 / 02-05 / 03-02 / 04$ & 4 & 112 \\
\hline & \multirow{3}{*}{ "Inverno" } & 1 & $13 / 03$ & $08 / 05-03 / 07-28 / 08-23 / 10$ & 4 & 224 \\
\hline & & 2 & $23 / 03$ & $18 / 05-13 / 07-07 / 09-03 / 11$ & 4 & 224 \\
\hline & & 3 & $02 / 04$ & $28 / 05-23 / 07-17 / 09-12 / 11$ & 4 & 224 \\
\hline
\end{tabular}

Obs: A aplicação da primeira época (parcelamento e aplicação total das adubações) deu-se em 11/11/1997, a partir desta data foram contados 10 dias para início da colheita das séries.

Os cortes foram realizados de acordo com os intervalos de dias estipulados para cada série, tendo cada série uma defasagem de 10 dias a partir da primeira série. O intervalo de dias para cada "estação" foi de 28 e 56 dias para verão e inverno respectivamente. Cada série foi cortada quatro vezes para ambas as estações, conforme foi apresentado na Tabela 2 e Figura 5.

As parcelas foram cortadas a $10 \mathrm{~cm}$ do solo com auxilio de uma motosegadeira, retirou-se $1 \mathrm{~m}$ de cada lado da parcela como bordadura, restando $4 \mathrm{~m}^{2}$ de área útil. As amostras eram pesadas e em seguida transportados para o Laboratório de Bromatologia do Departamento de Produção Animal- ESALQ/USP, em Piracicaba $\mathrm{SP}$, onde eram retiradas amostras representativas e colocadas em estufa de circulação de ar forçada a $65^{\circ} \mathrm{C}$ durante $72 \mathrm{~h}$ (Association Official Analytical Chemists - AOAC, 1995), em seguida o material era moido em moinho tipo Wiley com peneira de $1 \mathrm{~mm}$. 
O material foi homogeneizado e armazenado em saco plástico para posteriormente ser enviado para análises bromatológica e mineral.

Foram analisadas e calculadas as seguintes variáveis:

- produção de matéria seca (MS);

- teor de proteína bruta (PB);

- composição mineral (macronutrientes: N, P, K, Ca, Mg e S);

- extração de minerais;

- relação entre minerais (N:S, Ca:P);

A determinação da composição mineral do tecido vegetal (macronutrientes) foi realizada no Laboratório de Nutrição Mineral de Plantas do Departamento de Química da ESALQ/USP, sendo utilizadas as seguintes metodologias de análises químicas (Malavolta et al., 1989):

- nitrogênio: método semimicro Kjeldahl;

- fósforo: colorimetria do metavanadato (fósforo total);

- potássio: fotometria de chama;

- cálcio e magnésio: espectrofotometria de absorção atômica;

O enxofre foi determinado indiretamente em espectrofotometria de absorção atômica, com uso de sulfato de bário (Bataglia, 1976).

O teor de PB foi calculado através da multiplicação do $\mathrm{N}$ total pelo fator 6,25 (AOAC, 1995). 


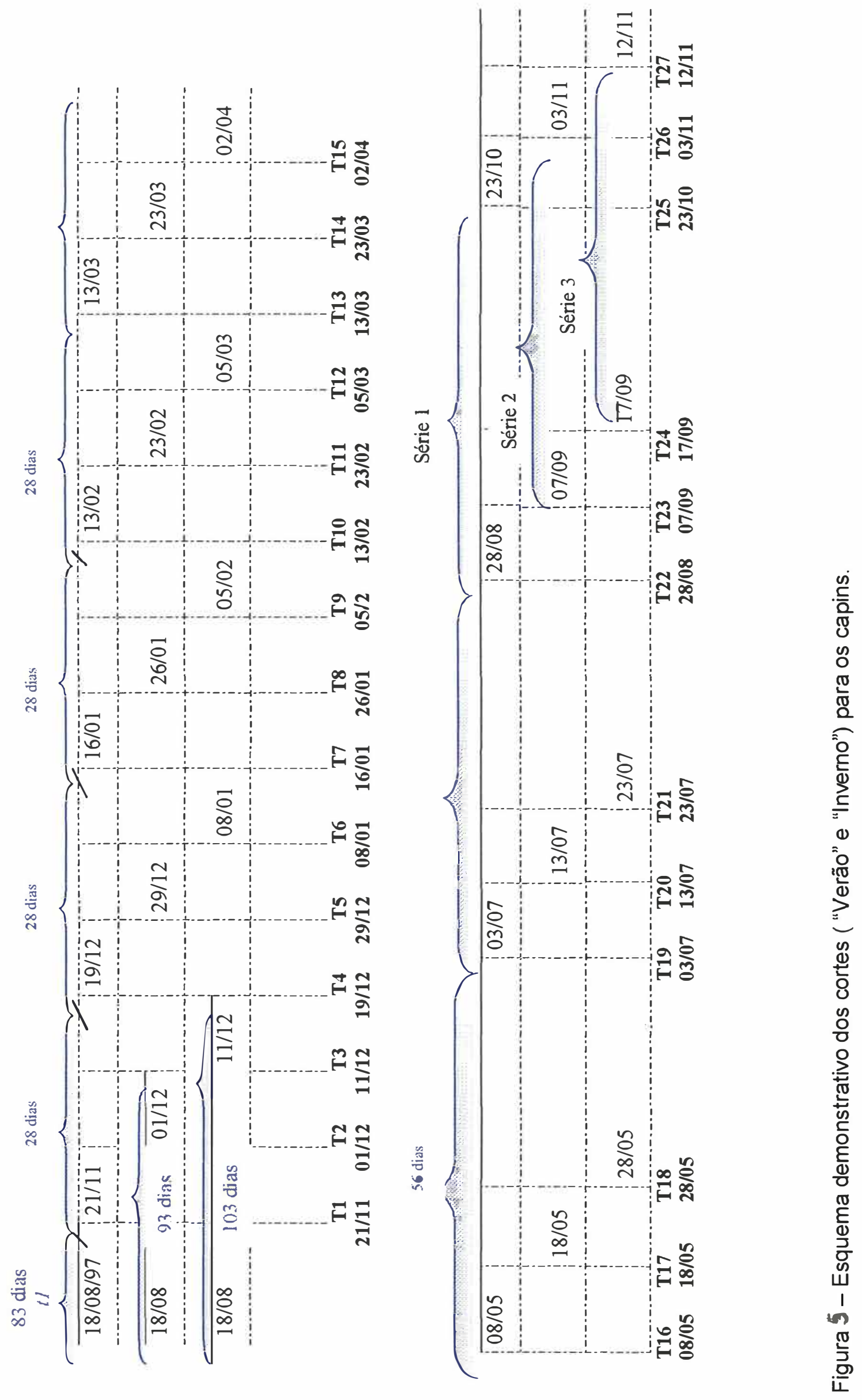




\subsection{Análises estatísticas}

Nas análises estatísticas foram utilizados os módulos SAS GLM e LAB do Sistema de Análises Estatísticas SAS (SAS Institute, 1988), onde foram obtidas análises de variância, testes de comparação de médias (teste $T$ de Student, ao nivel de $5 \%$ de significância) e análise exploratória dos dados, esta última apenas para uma variável.

Em função de resultados obtidos nas análises estatísticas, algumas variáveis foram transformadas para atender às hipóteses da análise de variância (SAS Institute, 1988).

O modelo estatístico utilizado está representado na Equação:

$$
y_{i j k r}=\mu+\alpha_{i}+\beta_{i}+\lambda_{k}+(\alpha \beta \lambda)_{i j k}+\gamma_{r}+e_{i j k r}
$$

onde: $y_{\mathrm{ijkr}}=$ resposta correspondente ao nivel $\mathrm{i}$ do fator doses de $\mathrm{N}$, com o nivel $\mathrm{j}$ do fator épocas de aplicação, com o nivel $k$ do fator período no bloco $r$;

$\mu=$ média geral;

$\alpha_{i}=$ é o efeito i-ésimo nivel do fator (doses de $\mathrm{N}$ );

$\beta_{\mathrm{j}}=$ é o efeito do j-ésimo nível do fator (épocas de aplicação);

$\lambda_{k}=$ é o efeito do k-ésimo nível do fator período ("verão" e "inverno")

$(\alpha \beta \lambda)_{\mathrm{ijk}}=$ é o efeito do da interação entre os niveis i de doses de $\mathrm{N}$ com o nivel $\mathrm{j}$ de épocas de aplicação e com o nivel k de periodos ("verão" e "inverno");

$\gamma_{r}=$ é o efeito do nivel r-ésimo do fator blocos;

$e_{i j k r}=$ erro devido à ijk-ésima parcela. 


\section{RESULTADOS E DISCUSSÃO}

\subsection{Panicum maximum cv. Mombaça}

\subsubsection{Produção de forragem}

Os resultados da produção de matéria seca $\left(g \cdot \mathrm{m}^{-2}\right)$ da parte aérea de Panicum maximum cv. Mombaça são apresentados na Tabela 3.

Tabela 3. Produção de matéria seca $\left(\mathrm{g} \cdot \mathrm{m}^{-2}\right)$ da parte aérea de Panicum maximum cv. Mombaça, em função dos períodos e épocas de aplicação de nitrogênio e suas distribuições percentuais (média de 9 repetições).

\begin{tabular}{|c|c|c|c|c|c|}
\hline \multirow{3}{*}{ Períodos(1! } & \multicolumn{5}{|c|}{ Epocas ${ }^{(1)}$} \\
\hline & $\begin{array}{l}\text { Aplicação Total } \\
\text { (Nov.) }\end{array}$ & \multicolumn{2}{|c|}{$\begin{array}{c}\text { Parcelamento } \\
\text { (1/2 Nov. e 1/2 Mar.) }\end{array}$} & \multicolumn{2}{|c|}{$\begin{array}{c}\text { Parcelamento } \\
\text { (1/3 Nov. e 2/3 Mar.) }\end{array}$} \\
\hline & \multicolumn{5}{|c|}{$\mathrm{MS}^{(2)}$} \\
\hline "Verão" & $66,48 \mathrm{~A} a$ & $68,74 \mathrm{~A} a$ & $59 \%$ & $70,47 \mathrm{~A} a$ & $59 \%$ \\
\hline "Inverno" & $42,53 \mathrm{~B} \mathrm{~b} \quad 39 \%$ & $47,90 \mathrm{~A} \mathrm{~b}$ & $41 \%$ & $49,14 \mathrm{~A} \mathrm{~b}$ & $41 \%$ \\
\hline Anual & 109,01 & 116,64 & & 119,61 & \\
\hline C.V. (\%): & $26,33^{(2)}$ & & & & \\
\hline
\end{tabular}

(1) Médias de periodos e épocas, seguidas de mesma letra maiúscula (linha) e minúscula (coluna), respectivamente. nầo diferem entre si pelo teste $t$-Student ao nivel de 0,05 de probabilidade.

(2) Transformação da variável $=(\text { Produção de matéria seca })^{0.3}$

Pelos resultados obtidos verificou-se que houve diferença significativa $(P<0,05)$ para períodos na produção de matéria seca no inverno. A produção de MS sofreu redução no período de "inverno" em relação ao "verão", tendo o tratamento de aplicação total em nov., apresentado uma produção menor quando comparado com os tratamentos parcelados, que não diferiram significativamente entre si.

A distribuição da produção de matéria seca observada, esteve de acordo com os resultados obtidos por Valentim e Moreira (1994), que determinaram que, 
produção anual de forragem (1900g. $\mathrm{m}^{-2} \cdot$ ano $^{-1}$ ) $60 \%$ ocorreu no período chuvoso e $40 \%$ no período seco.

Andrade et al. (1991) conduzindo experimento durante dois anos, num ensaio de adubação nitrogenada ( 80 e $240 \mathrm{~kg}$ de N.ha ${ }^{-1} \cdot a^{-1}$ ) comparando três capins da espécie Panicum maximum Jacq. quanto à produção de MS com freqüências corte (42 dias no "verão" e 56 dias no "inverno") para todos os tratamentos, na qual houve diferença significativa $(P<0,01)$ entre as doses estudadas, onde na menor dose aplicada de $\mathrm{N}$ foi verificada uma maior participação percentual da produção de matéria seca dos capins no "inverno" em relação à produção anual para a menor dose de $\mathrm{N}$. Comparando-se com as produções de matéria seca encontradas, as mesmas estavam de acordo, haja visto, que as maiores produções no "inverno" foram atribuídas as aplicações parceladas

Pedreira e Mattos (1981) relataram que a espécie Panicum maximum apresentou uma acentuada estacionalidade quando se avaliou a produção de matéria seca de 25 capins obtendo baixas taxas de crescimento no "inverno" (11\%) em relação a produção total anual, entretanto, os resultados obtidos, mostram o efeito das épocas de aplicação de $\mathrm{N}$ amenizando a estacionalidade da espécie estudada, apresentando distribuições em média $42 \%$ no "inverno".

\subsubsection{Composição bromatológica}

A composição bromatológica, via de regra, fornece alguns indicadores do potencial nutritivo das plantas forrageiras. O conhecimento de sua variação nos diversos estádios fenológicos é um dos fatores a ser considerado para a utilização de práticas de manejo adequadas. Em geral, à medida que as gramíneas tropicais envelhecem, há uma redução nos teores de proteína bruta e minerais e elevação, dos teores de matéria seca (Costa, 1997).

Os teores de proteina bruta do capim Panicum maximum cv. Mombaça foram obtidos a partir do produto dos teores de nitrogênio em cada período pelo fator 6,25 , apresentados na Tabela 4 
Tabela 4. Teores de proteína bruta $\left(\mathrm{g} \cdot \mathrm{kg}^{-1}\right)$ na matéria seca da parte aérea de Panicum maximum cV. Mombaça em função dos periodos estacionais e suas distribuições percentuais (média de nove repetições).

\begin{tabular}{lll}
\hline \multicolumn{2}{c}{ Períodos $^{(1)}$} & PB $\left(\mathrm{g} \cdot \mathrm{kg}^{-1}\right)^{(2)}$ \\
\hline "Verão" & $98,36 \mathrm{~A}$ & $53 \%$ \\
"Inverno" & $87,22 \mathrm{~B}$ & $47 \%$ \\
Teor de PB total & 185,58 & \\
C.V. (\%) & 20,72 \\
(") Médias de periodos seguidas de mesma letra maiúscula (coluna) não diferem entre si pelo teste t-Student ao nivel de \\
0,05 de probabilidade.
\end{tabular}

Os valores obtidos para os teores de PB sofreram decréscimos de um período para o outro. A queda destes teores podem ter como explicação, a maior presença de folhas velhas ou senescentes no material coletado no período de "inverno" com idade mais avançada, com aumento na proporção de hastes, cuja concentração protéica é menor a das folhas e devido à diminuição na concentração de proteína nas frações folha e haste, (Minson, 1992). A possivel fixação do nitrogênio em estruturas da parede celular descrito por Van Soest (1982). A maior produção e acúmulo de matéria seca, causando efeito de diluição de proteína e minerais (Gomide, 1978). Além das causas fisiológicas como a exportação de nutrientes para locais de maior atividade, segundo Sampaio (1973).

Euclides (1995) mostrou que as gramíneas do gênero Panicum quando novas, apresentam concentrações de PB adequados para a produção máxima (190g. $\mathrm{kg}^{-1}$ Colonião; $160 \mathrm{~g} \cdot \mathrm{kg}^{-1}$ Tobiatã e $161 \mathrm{~g} \cdot \mathrm{kg}^{-1}$ Tanzânia). Entretanto quando maduras, a concentração de PB atinge teores próximos do crítico $\left(95 ; 91\right.$ e $74 \mathrm{~g} \cdot \mathrm{kg}^{-1}$ para Colonião, Tobiatã e Tanzânia, respectivamente).

Segundo Raymond (1969), os valores de PB devem-se situar acima de $70 \mathrm{~g} . \mathrm{kg}^{-1}$ para satisfazer às exigências de manutenção de bovinos e eqüinos, valores estes, encontrados no presente trabalho. 


\subsubsection{Composição mineral}

De maneira geral, as gramíneas tropicais demonstram baixo teores de minerais. Concentrações diferentes de qualquer um dos 15 elementos considerados essenciais para o animal, limitam o consumo e utilização da forrageira. A concentração dos minerais varia com a espécie e o cultivar, o estádio de crescimento e a disponibilidade no solo (Euclides, 1995).

$\mathrm{Na}$ Tabela 5 a 10 são apresentadas o teor de alguns macronutrientes como: nitrogênio $(\mathrm{N})$, fósforo $(\mathrm{P})$, potássio $(\mathrm{K})$, cálcio $(\mathrm{Ca})$, magnésio $(\mathrm{Mg})$ e enxofre $(\mathrm{S})$, na matéria seca da parte aérea de Panicum maximum cv. Mombaça.

\section{Nitrogênio}

Os resultados para os teores de $\mathrm{N}\left(\mathrm{g} \cdot \mathrm{kg}^{-1}\right)$ na matéria seca da parte aérea de Panicum maximum cv. Mombaça encontram-se reunidos na Tabela 5.

Tabela 5. Teores de $\mathrm{N}$ na matéria seca da parte aérea de Panicum maximum cv. Mombaça em função dos períodos estacionais (média de nove repetições).

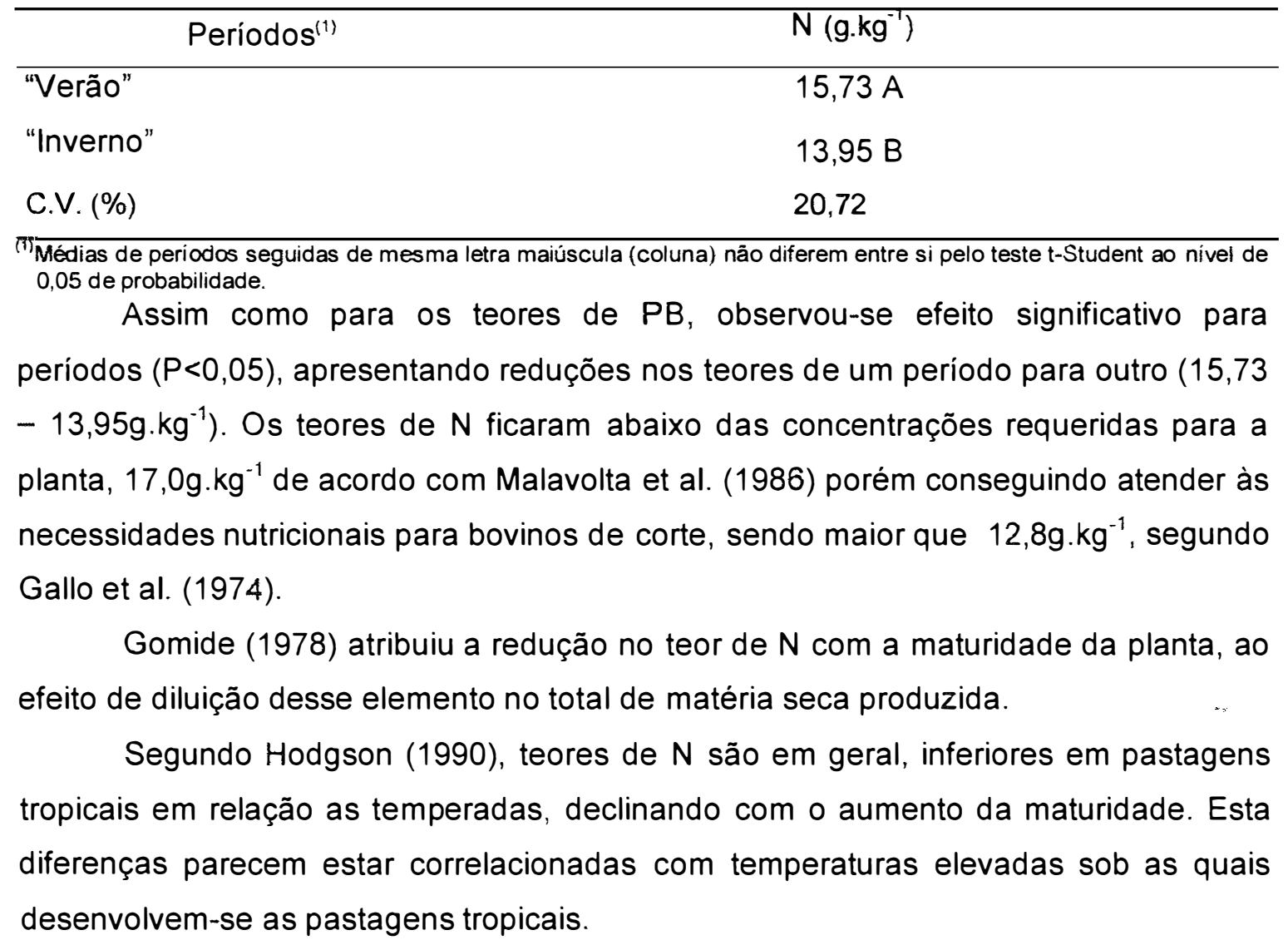


Euclides (1995) relata que as médias dos teores de alguns macronutrientes em três cultivares de Panicum maximum, em amostras simulando o pastejo animal, no períodos das águas e da seca, durante três anos, encontrou valores de $\mathrm{N}$ de $21,0 \mathrm{~g} \cdot \mathrm{kg}^{-1}$ e $12,0 \mathrm{~g} \cdot \mathrm{kg}^{-1}$, respectivamente.

\section{Fósforo}

Os resultados para os teores de $\mathrm{P}\left(\mathrm{g} \cdot \mathrm{kg}^{-1}\right)$ na matéria seca da parte aérea de Panicum maximum cv. Mombaça encontram-se reunidos na Tabela 6.

Tabela 6. Teores de $\mathrm{P}\left(\mathrm{g} \cdot \mathrm{kg}^{-1}\right)$ na matéria seca da parte aérea de Panicum maximum cV. Mombaça em função dos períodos e épocas de aplicação de nitrogênio (média de nove repetições).

\begin{tabular}{cccc}
\hline & \multicolumn{4}{c}{ Épocas $^{(1)}$} \\
\cline { 2 - 4 } & $\begin{array}{c}\text { Aplicação Total } \\
\text { (Nov.) }\end{array}$ & $\begin{array}{c}\text { Parcelamento } \\
(1 / 2 \text { Nov. e 1/2 Mar.) }\end{array}$ & $\begin{array}{c}\text { Parcelamento } \\
(1 / 3 \text { Nov. e 2/3 Mar.) }\end{array}$ \\
\hline "Verão" & $3,44 \mathrm{~B} \mathrm{a}$ & $3,55 \mathrm{AB} \mathrm{a}$ & $3,57 \mathrm{~A}$ a \\
"Inverno" & $2,87 \mathrm{~A} \mathrm{~b}$ & $2,56 \mathrm{BC} \mathrm{b}$ & $2,48 \mathrm{C}$ b \\
\hline C.V. (\%): & 15,41 & & \\
\hline
\end{tabular}

(1)Médias de períodos e épocas, seguidas de mesma letra maiúscula (linha) e minúscula (coluna), respectivamente, não diferem entre si pelo teste $t$-Student ao nivel de 0,05 de probabilidade.

Os teores de $P$ apresentaram diferença significativa $(P<0,05)$, para a interação períodos e épocas de aplicação de fertilizante nitrogenado.

Verificou-se diferença significativa $(P<0,05)$ entre os periodos, com valores superiores no período de "verão" em relação ao "invemo". Os teor de P na aplicação total foi menor que os parcelamentos, que não diferiram entre si.

Os resultados obtidos na interação periodos e épocas estão de acordo com os teores, quando comparados à faixa de concentração normal na planta e à exigência de bovinos, 2 - $4 \mathrm{~g} \cdot \mathrm{kg}^{-1}$ e $1,8-4,3 \mathrm{~g} \cdot \mathrm{kg}^{-1}$, respectivamente, (Gallo et al. 1974), e do teor médio em gramineas no Estado de São Paulo $\left(2,1 \mathrm{~g} \cdot \mathrm{kg}^{-1}\right)$, apresentado por Malavolta et al. (1986).

Segundo Souza (1986a), no período chuvoso quando as plantas ainda estão verdes, as concentrações de $P$ em algumas espécies como o colonião, jaraguá e gordura são bem mais elevadas, chegando algumas vezes a concentrações superiores às necessidades nutricionais mínimas $\left(1,8 \mathrm{~g} \cdot \mathrm{kg}^{-1}\right)$, para bovinos de corte. Entretanto, no 
periodo seco, em que as pastagens encontram-se secas ou maduras, os teores de $P$ sofrem grandes reduções, contribuindo para uma média geral inferior às recomendações mínimas mencionadas.

Segundo Haag e Dechen (1994), os teores de $P$ encontrados nas plantas normais e deficientes de colonião variam de 1,1 a 0,8 e 0,8 a $0,05 \mathrm{~g} \cdot \mathrm{kg}^{-1}$ respectivamente, portanto, os valores obtidos neste trabalho, estão acima dos teores citados pelos autores.

Os significativos teores de $P$ encontrados, podem ser devido aos bons niveis deste elemento no solo, verificado na análise prévia, uma vez que sua concentração na planta é bastante influenciada por sua disponibilidade no meio (Gomide, 1976; Mengel e Kirkby, 1987).

\section{Potássio}

Os resultados para os teores de $\mathrm{K}\left(\mathrm{g} \cdot \mathrm{kg}^{-1}\right)$ na matéria seca da parte aérea de Panicum maximum cv. Mombaça encontram-se reunidos na Tabela 7 e 8.

Tabela 7. Teores de $\mathrm{K}$ na matéria seca da parte aérea de Panicum maximum cv. Mombaça em função dos periodos estacionais (média de nove repetições).

\begin{tabular}{lc}
\multicolumn{1}{l}{ Períodos ${ }^{(1)}$} & $\mathrm{K}\left(\mathrm{g} \cdot \mathrm{kg}^{-1}\right)$ \\
"Verão" & $18,14 \mathrm{~A}$ \\
"Inverno" & $14,90 \mathrm{~B}$ \\
C.V. (\%) & 21.22 \\
(1) Médias de periodos seguidas de mesma letra maiúscula (coluna) não diferem entre si pelo teste t-Student ao nivel de \\
O.05 de probabilidade. \\
Observou-se efeito significativo (P<0,05) tanto entre periodos quanto para a \\
interação ocorrida entre doses de adubação nitrogenada e épocas de aplicação.
\end{tabular}


Tabela 8. Teores de $\mathrm{K}\left(\mathrm{g}_{\mathrm{kg}} \mathrm{kg}^{-1}\right)$ na matéria seca da parte aérea de Panicum maximum cv. Mombaça em função de doses e épocas de aplicação de nitrogênio (média de nove repetições).

\begin{tabular}{|c|c|c|c|}
\hline \multirow{2}{*}{$\begin{array}{l}\text { Doses }^{(1)} \\
(\mathrm{kg} \text { de } N)\end{array}$} & \multicolumn{3}{|c|}{ Epocas $^{(1)}$} \\
\hline & $\begin{array}{c}\text { Aplicação Total } \\
\text { (Nov.) }\end{array}$ & $\begin{array}{c}\text { Parcelamento } \\
\text { (1/2 Nov. e 1/2 Mar.) }\end{array}$ & $\begin{array}{c}\text { Parcelamento } \\
\text { (1/3 Nov. e 2/3 Mar.) }\end{array}$ \\
\hline 50 & $16,87 \mathrm{~A} a$ & $16,74 \mathrm{Ab}$ & $16,31 \mathrm{Aa}$ \\
\hline 100 & $15,68 \mathrm{~B} \mathrm{~b}$ & $17,66 \mathrm{~A} a$ & $16,96 \mathrm{~A} a$ \\
\hline 150 & $13,06 \mathrm{~A} \mathrm{~b}$ & $16,11 \mathrm{AC}$ & $16,32 \mathrm{~A} a$ \\
\hline
\end{tabular}

C.V. (\%): 21,22

(1) Médias de doses e épocas, seguidas de mesma letra maiúscula (linha) e minúscula (coluna), respectivamente, não diferemrentre si pelo teste $t-S t u d e n t$ ao nivel de 0,05 de probabilidade.

Os períodos diferiram significativamente entre si, sendo o teor no período de "verão" maior que no período de "inverno".

Em função das doses de $\mathrm{N}$ aplicadas dentro cada uma das épocas, os teores de $K$ diferiram significativamente $(P<0,05)$ apenas para 0 tratamento de dose 100 e aplicação total em nov. (com menor teor igual a $15,68 \mathrm{~g}_{\mathrm{kg}} \mathrm{g}^{-1}$ ) quando comparado com os tratamentos parcelados, que não diferiram entre si. 0 mesmo ocorreu quando comparou-se as três doses dentro de uma mesma época, apresentando 100 (1/2 em nov. e $1 / 2$ em mar.) com teor $\left(17,66 \mathrm{~g} \cdot \mathrm{kg}^{-1}\right)$ superior aos demais.

Os teores encontrados no presente trabalho, estão de acordo com os apresentados por Gallo et al. (1974) de $12-28 \mathrm{~g} \cdot \mathrm{kg}^{-1}$, com os descritos por Haag e Dechen (1994) de 13 - 40 g. $\mathrm{kg}^{-1}$ para gramíneas forrageiras no Brasil e enquadrados nos valores obtidos por Mcdowell (1985) em gramíneas tropicais com teores acima de $8,0 \mathrm{~g} \cdot \mathrm{kg}^{-1}$.

Euclides (1995) determinando médias de teores de $K$ de três cultivares de Panicum maximum, no períodos das águas e da seca, encontrou valores de $17,8 \mathrm{e}$ $12,8 \mathrm{~g} \cdot \mathrm{kg}^{-1}$, respectivamente.

Segundo o NRC (1996) os teores estão acima da concentração recomendada para as algumas categorias de bovinos de corte $\left(6,0 \mathrm{~g} \cdot \mathrm{kg}^{-1}\right)$. 


\section{Cálcio e Magnésio}

Os resultados para os teores de $\mathrm{Ca}$ e $\mathrm{Mg}\left(\mathrm{g} \cdot \mathrm{kg}^{-1}\right)$ na matéria seca da parte aérea de Panicum maximum cv. Mombaça encontram-se reunidos na Tabela 9, haja visto que houve efeito significativo $(P<0,05)$ em ambos, somente para os períodos estacionais estudados.

Tabela 9. Teores de $\mathrm{Ca}$ e $\mathrm{Mg}$ na matéria seca da parte aérea de Panicum maximum cv. Mombaça em função dos períodos estacionais (média de nove repetições).

\begin{tabular}{lcc}
\hline \multicolumn{1}{c}{ Períodos $^{(1)}$} & $\mathrm{Ca}\left(\mathrm{g} \cdot \mathrm{kg}^{-1}\right)$ & $\mathrm{Mg}\left(\mathrm{g} \cdot \mathrm{kg}^{-1}\right)$ \\
\cline { 2 - 3 } "Verão" & $4,01 \mathrm{~B}$ & $3,72 \mathrm{~B}$ \\
"inverno" & $5,91 \mathrm{~A}$ & $4,01 \mathrm{~A}$ \\
C.V. (\%) & 21,28 & 21,97
\end{tabular}

(1) Médias de periodos seguidas de mesma letra maiúscula (coluna) não diferem entre si pelo teste t-Student ao nivel de 0,05 de probabilidade.

Observou-se tanto para os teores de $\mathrm{Ca}$ como os $\mathrm{Mg}$ a diferença significativa $(P<0,05)$ entre os períodos de "verão" e "inverno". Para Ca e Mg os teores obtidos no período do "inverno" foram superiores aos do "verão", apresentando uma diferença entre teores de $1,90 \mathrm{~g} \cdot \mathrm{kg}^{-1}$ e $0,29 \mathrm{~g} \cdot \mathrm{kg}^{-1}$, respectivamente.

Segundo Gomide (1969a) a variação nos teores de Ca pode ser explicada em função da idade da planta, podendo apresentar tendências distintas para cada espécie, sendo estável, decrescendo ou apresentando comportamentos variáveis durante todo o período. Souza (1986b) justifica que elementos como o Ca e Mg são quase imóveis, portanto, aumentam no tecido vegetal à medida que a planta envelhece. $O$ autor reuniu amostras coletadas no periodo chuvoso e seco, apresentando médias das duas amostragens para colonião (212 observações) cujos teores foram de $5,8 \mathrm{~g} \cdot \mathrm{kg}^{-1} \mathrm{e}$ $2,8 \mathrm{~g} \cdot \mathrm{kg}^{-1}$ para $\mathrm{Ca}$ e $\mathrm{Mg}$, respectivamente.

Os teores de $\mathrm{Ca}$ obtidos, estão acima dos valores encontrados por Gallo et al. (1974) de 2 a $4 \mathrm{~g} \mathrm{~kg}^{-1}$ por (1994) que apresentou concentrações entre 1,2 e 4,0g. $\mathrm{kg}^{-1}$ para gramineas forrageiras no Brasil. $\mathrm{O}$ mesmo pode-se atribuir ao $\mathrm{Mg}$, apresentando valores acima dos normais descritos por Malavolta et al. (1986), 2,7g. $\mathrm{kg}^{-1}$, dos intervalos de 1,2 a 2,6g. $\mathrm{kg}^{-1}$, descritos por Gallo et al. (1974) e Haag e Dechen (1984) 1,0 a $2,7 \mathrm{~g} \cdot \mathrm{kg}^{-1}$. Para o NRC (1996), tanto os teores de Ca $\left(1,9\right.$ a $\left.7,3 \mathrm{~g} \cdot \mathrm{kg}^{-1}\right)$ como os de 
$\mathrm{Mg}\left(1,0\right.$ a $\left.2,0 \mathrm{~g} \cdot \mathrm{kg}^{-1}\right)$ atenderiam às exigências de minerais, recomendadas para bovinos de corte.

\section{Enxofre}

Os resultados para os teores de $S\left(\mathrm{~g} \cdot \mathrm{kg}^{-1}\right)$ na matéria seca da parte aérea de Panicum maximum cv. Mombaça encontram-se reunidos na Tabela 10.

Tabela 10. Teores de $\mathrm{S}\left(\mathrm{g}_{\mathrm{kg}} \mathrm{kg}^{-1}\right)$ na matéria seca da parte aérea de Panicum maximum cv. Mombaça em função dos periodos e épocas de aplicação de nitrogênio (média de nove repetições).

\begin{tabular}{cccc}
\hline & \multicolumn{3}{c}{ Épocas"(1) } \\
\cline { 2 - 4 } Periodos" & Aplicação Total & Parcelamento & Parcelamento \\
& $($ Nov. $)$ & $(1 / 2$ Nov. e 1/2 Mar. $)$ & $(1 / 3$ Nov. e 2/3 Mar. $)$ \\
\hline "Verão" & $1,41^{(2)} \mathrm{A} \mathrm{a}$ & $1,37 \mathrm{~A} \mathrm{a}$ & $1,39 \mathrm{~A} \mathrm{a}$ \\
"Inverno" & $1,39 \mathrm{~A}$ a & $1,15 \mathrm{~B} \mathrm{~b}$ & $1,14 \mathrm{~B} \mathrm{~b}$ \\
\hline C.V. (\%): & 8,35 &
\end{tabular}

\footnotetext{
${ }^{(1)}$ Médias de períodos e épocas, seguidas de mesma letra maiúscula (linha) e minúscula (coluna), respectivamente, não diferem entre si pelo teste $t-S t u d e n t$ ao nivel de 0,05 de probabilidade.

(2) Transformaçāo da variável $S=(S)^{0,03}$
}

Os teores de $S$ obtidos, apresentaram diferença significativa $(P<0,05)$, entre periodos de "verão" e "inverno" para as épocas em que houve o parcelamento dos tratamentos. Verificou-se que os teores encontrados, foram superiores no periodo de "verão" em relação aos do "inverno".

Apesar dos teores de S no periodo de "inverno" diferirem apenas entre as épocas de aplicação total $\left(1,39 \mathrm{~g} \cdot \mathrm{kg}^{-1}\right)$ e os parcelamentos $\left(1,15 \mathrm{~g} \cdot \mathrm{kg}^{-1}\right.$ e $\left.1,14 \mathrm{~g} \cdot \mathrm{kg}^{-1}\right)$, notou-se uma tendência de decréscimo destes teores, conforme a época de aplicação do nitrogênio.

Euclides (1995) apresentou médias de teores de macronutrientes na folha indice de dois cultivares de Panicum maximum (entre eles, o Mombaça) para $S$ de $1,35 \mathrm{~g} \cdot \mathrm{kg}^{-1}$. Comparando-se esse valor com os teores encontrados no periodo de "verão", no presente trabalho, encontram-se de acordo com o teor apresentado pela autora.

Macedo et al. (1993), obtiveram teores médios de $S$ em três cultivares de Panicum maximum em amostras simulando o pastejo animal, nos periodos das águas 
e da seca sendo estes $1,62 \mathrm{~g} \cdot \mathrm{kg}^{-1}$ e $1,48 \mathrm{~g} \cdot \mathrm{kg}^{-1}$ ( $1^{\circ}$ ano); $1,64 \mathrm{~g} \cdot \mathrm{kg}^{-1}$ e $1,20 \mathrm{~g} \cdot \mathrm{kg}^{-1}$ (2 ano) e $1,40 \mathrm{~g} \cdot \mathrm{kg}^{-1}$ e $1,52 \mathrm{~g} \cdot \mathrm{kg}^{-1}$ (3ㅇan ano, respectivamente.

Os teores de $S$ obtidos estão acima da concentração média $\left(1 \mathrm{~g} \cdot \mathrm{kg}^{-1}\right)$ observada por Malavolta et al. (1986) em gramíneas no Estado de São Paulo também, confirmados por Gallo et al. (1974) que consideraram como concentração normal de S nas plantas, o intervalo de $1 \mathrm{a} 3 \mathrm{~g} \mathrm{~kg}^{-1}$.

\section{Relações entre nutrientes}

Algumas das principais relações entre nutrientes existentes $N / S$ e $C a / P$, foram calculadas para matéria seca da parte aérea de Panicum maximum cv. Mombaça são apresentadas nas Tabelas 11 e 12.

Tabela 11. Relação entre os nutrientes N/S calculadas na matéria seca da parte aérea de Panicum maximum cv. Mombaça em função das épocas de aplicação de nitrogênio (média de nove repetições).

\begin{tabular}{ll}
\hline \multicolumn{1}{c}{ Épocas $^{(1)}$} & \multicolumn{1}{c}{ N/S $^{(2)}$} \\
\hline Aplicação Total (Nov.) & $11,28 \mathrm{~B}$ \\
Parcelamento (1/2 Nov. e 1/2 Mar.) & $12,40 \mathrm{~A}$ \\
Parcelamento (1/3 Nov. e 2/3 Mar.) & $12,54 \mathrm{~A}$ \\
C.V. (\%) & 8,60
\end{tabular}

(1) Médias de épocas seguidas de mesma letra maiúscula (coluna) não diferem entre si pelo teste t-Student ao nível de 0,05 de probabilidade.

(2) Transformação da variável N/S $=(\mathrm{N} / \mathrm{S})^{003}$

A relação N/S diferiu significativamente $(P<0,05)$ entre aplicação total de $N$ e os parcelamentos realizados. A época de aplicação total em nov apresentou menor relação N/S do que os parcelamentos empregados.

Apenas os parcelamentos atingiram o limite mínimo do intervalo adequado das relações N/S (12/1 a 15/1), considerado ideal por Follet e Wilkinson (1995) para a máxima produção vegetal. As baixas relações N/S observadas, podem ser atribuídas aos baixos teores de $\mathrm{N}$ encontrados e manutenção nos teores de $\mathrm{S}$ com o aumento da idade da planta.

Segundo Vitti e Novaes (1986) um dos índices mais comuns para avaliar o estado nutricional da planta, quanto ao $\mathrm{S}$, bem como para avaliar a produção máxima de forragens e a adequada nutrição animal, é a relação N/S no tecido da planta. Essa 
relação, possui a vantagem de permanecer quase que constante nos diversos estádios de desenvolvimento da planta. Trabalhos demonstrando a importância dessa relação, como indicativo da performance da forragem, são muitos. Quando a planta atinge a maturidade, a relação N/S tende a se estabilizar em 14/1 nas gramíneas, sendo que uma relação N/S de 20/1 nas gramíneas ocorreria severa deficiência de $S$. A deficiência de $S$ reduz a quantidade de $N$ produzido, restringindo o crescimento da planta, haja visto, que uma das principais funções do $S$ é a conversão do $\mathrm{N}$ não protéico em proteico, seja o absorvido do solo, seja o absorvido da atmosfera via sistema simbiótico das leguminosas

Humphreys (1991) a relação N/S desejada de 14/1 e que, baixos teores de $S$ inibem a formação de proteína.

Van Soest (1994), cita que a relação satisfatória para atender às exigências dos microorganismos ruminais è de 12/1, neste caso, as relações encontradas em Panicum maximum cv. Mombaça seriam suficientes para tal, apenas para as épocas parceladas. Contudo, outros autores como Mcdowell (1985) e o NRC (1996) recomendam uma relação de $10 / 1$ a 14/1 como sendo ideal à nutrição animal.

Tabela 12. Relação entre os nutrientes Ca/P calculadas na matéria seca da parte aérea de Panicum maximum cv. Mombaça, em função das doses de adubação nitrogenada, períodos e épocas de aplicação nitrogênio (média de nove repetições).

\begin{tabular}{|c|c|c|c|c|}
\hline \multirow{2}{*}{ Períodos") } & \multirow{2}{*}{$\begin{array}{l}\text { Doses }^{(1)} \\
(\mathrm{kg} \text { de } N)\end{array}$} & \multicolumn{3}{|c|}{ Épocas $^{(1)}$} \\
\hline & & $\begin{array}{c}\text { Aplicação Total } \\
\text { (Nov.) }\end{array}$ & $\begin{array}{c}\text { Parcelamento } \\
\text { (1/2 Nov. e } 1 / 2 \text { Mar.) }\end{array}$ & $\begin{array}{c}\text { Parcelamento } \\
\text { (1/3 Nov. e 2/3 Mar.) }\end{array}$ \\
\hline \multirow{3}{*}{ "Verão" } & 50 & $1,10 \mathrm{~A} C$ & $1,15 \mathrm{~A} \mathrm{C}$ & $1,11 \mathrm{~A} \mathrm{C}$ \\
\hline & 100 & $1,25 \mathrm{~A} \mathrm{bc}$ & $1,05 \mathrm{~B} \mathrm{C}$ & $1,14 \mathrm{~B} \mathrm{C}$ \\
\hline & 150 & $1,30 \mathrm{~A} \mathrm{~b}$ & $1,19 A \mathrm{C}$ & $1,19 \mathrm{~A} C$ \\
\hline \multirow{4}{*}{ "Inverno" } & 50 & $2,03 \mathrm{~A} a$ & $2,15 \mathrm{~A} \mathrm{~b}$ & $2,13 \mathrm{Ab}$ \\
\hline & 100 & $2,10 \mathrm{~B}$ a & $2,26 \mathrm{~B} \mathrm{~b}$ & $2,67 \mathrm{~A} a$ \\
\hline & 150 & $2,21 \mathrm{~B} a$ & $2,68 \mathrm{~A} a$ & $2,77 \mathrm{~A} a$ \\
\hline & C.V. $(\%)$ & 27,67 & & \\
\hline
\end{tabular}

(1)Médias de épocas e doses, seguidas de mesma letra maiúscula (linha) e minúscula (coluna), respectivamente, não diferem entre si pelo teste $t$-Student ao nivel de 0,05 de probabilidade. 
Pelos dados da Tabela 12, verifica-se que houve um efeito significativo $(P<0,05)$ da interação doses de $N \times$ periodos $x$ épocas de aplicação do fertilizante. As relações $\mathrm{Ca} / \mathrm{P}$ que diferiram significativamente entre os periodos, apresentando relações maiores para o periodo de "inverno" que do "verão".

Para o periodo do "verão" apenas no tratamento $100 \mathrm{~kg} \mathrm{~N}$ (aplicação total em nov.) foi observada diferença significativa entre cada uma das épocas comparadas.

No periodo do "inverno", as relações apresentaram comportamentos bastante diferentes, para o tratamento $100 \mathrm{~kg}$ de $N$ parcelamento $1 / 3 \mathrm{em}$ nov. e 2/3 em mar. apresentou melhor relação Ca/P do que o parcelamento 1/2 em nov. e 1/2 em mar e a aplicação total em nov, já para a dose $150 \mathrm{~kg}$ de $\mathrm{N}$ a menor relação Ca/P foi atribuida a aplicação total em nov.

Ao comparar-se doses entre si dentro de cada uma das épocas, pode-se observar que para a aplicação total em nov., as maiores relações Ca/P foram atribuidas as tres doses no periodo de "inverno". O parcelamento 1/2 em nov. e 1/2 em mar. a dose $150 \mathrm{~kg}$ de $\mathrm{N}$ obteve melhor relação $\mathrm{Ca} / \mathrm{P}(2,68 / 1)$ enquanto que, para época de parcelamento $1 / 3$ em nov. e 2/3 em mar. as doses 100 e $150 \mathrm{~kg}$ de $\mathrm{N}$ apresentaram melhores relações do que a dose 50 , apesar das mesmas não diferirem significativamente entre si.

Em relação as diferenças encontradas entre os periodos, as relações $\mathrm{Ca} / \mathrm{P}$ apresentam valores maiores no "inverno" em relação ao "verão", explicado pelo próprio comportamento fisiológico da planta produzindo maior quantidade de MS, no periodo de "verão" em decorrência das condições climática favoráveis (por ex. luz e umidade do solo) comparados com o "inverno", onde o empenho está na produção de parede celular, cujo principal constituinte é o $\mathrm{Ca}$.

De acordo com o NRC (1996), relações Ca/P entre $1 / 1$ e $1 / 7$, resultam em desempenhos similares, desde que o consumo de fósforo seja suficiente para atender às exigências. Entretanto, segundo Boin (1986), quando as exigências de $P$ são atendidas, a relação Ca/P deixa de ser menos importante. 


\section{Conteúdo de nutrientes}

Os conteúdos de N, P e Ca $\left(\mathrm{g} \cdot \mathrm{m}^{-2}\right)$ na matéria seca da parte aérea do Panicum maximum cv. Mombaça estão reunidos na Tabela 13.

Tabela 13. Conteúdos de $\mathrm{N}, \mathrm{P}$ e Ca na matéria seca $\left(\mathrm{g} \cdot \mathrm{m}^{-2}\right)$ da parte área do Panicum maximum cv. Mombaça, em função dos períodos e épocas de aplicação de nitrogênio (média das nove repetições).

\begin{tabular}{|c|c|c|c|c|c|}
\hline \multirow{2}{*}{$\begin{array}{c}\text { Extrações de } \\
\text { nutrientes } \\
\left(\mathrm{g} \cdot \mathrm{m}^{-2}\right)\end{array}$} & \multirow{2}{*}{ Períodos $^{(1)}$} & \multicolumn{3}{|c|}{ Épocas(1) } & \multirow[b]{2}{*}{$\begin{array}{l}\text { C.V. } \\
(\%)\end{array}$} \\
\hline & & $\begin{array}{c}\text { Aplicação } \\
\text { total (Nov.) }\end{array}$ & $\begin{array}{c}\text { Parcelamento } \\
\text { (1/2 Nov. e 1/2 Mar.) }\end{array}$ & $\begin{array}{c}\text { Parcelamento } \\
\text { (1/3 Nov. e } 2 / 3 \text { Mar.) }\end{array}$ & \\
\hline \multirow[t]{2}{*}{$N^{(2)}$} & "Verão" & $0,035 \mathrm{~A} a$ & $0,027 \mathrm{~A} a$ & $0,030 \mathrm{~A} a$ & \multirow[t]{2}{*}{18,08} \\
\hline & "Inverno" & $0,006 \mathrm{~B} b$ & $0,011 \mathrm{~A} \mathrm{~b}$ & $0,013 \mathrm{~A} \mathrm{~b}$ & \\
\hline \multirow{2}{*}{$P^{(2)}$} & "Verão" & $0,007 \mathrm{~A} a$ & $0,006 \mathrm{~A} a$ & $0,007 \mathrm{~A} a$ & \multirow{2}{*}{22,97} \\
\hline & "Inverno" & $0,001 \mathrm{~B} \mathrm{~b}$ & $0,002 \mathrm{~A} \mathrm{~b}$ & $0,002 \mathrm{~A} \mathrm{~b}$ & \\
\hline \multirow{2}{*}{$\mathrm{Ca}^{(2)}$} & "Verão" & $0,008 \mathrm{~A} a$ & $0,007 \mathrm{~A} a$ & $0,007 \mathrm{~A} a$ & \multirow{2}{*}{18,93} \\
\hline & "Inverno" & $0,002 \mathrm{~B} \mathrm{~b}$ & $0,005 \mathrm{~A} b$ & $0,006 \mathrm{Ab}$ & \\
\hline
\end{tabular}

No conteúdo dos nutrientes houve efeito significativo $(P<0,05)$ de interação entre períodos e épocas de aplicação, assim como observou-se diferença significativa entre os períodos estudados ("verão" e "inverno"), onde os conteúdos obtidos no período de "verão" mostraram-se maiores em relação as do "inverno".

$\mathrm{Na}$ Tabela 13, os conteúdos de $\mathrm{N}, \mathrm{P}$ e $\mathrm{Ca}\left(\mathrm{g} \cdot \mathrm{m}^{2}\right)$ diferiram significativamente $(P<0,05)$ para períodos, observando-se que no "inverno" as quantidades obtidas, diferiram quanto à época aplicada, sendo o tratamento de aplicação total em nov. apresentado os menores conteúdos, em relação ao tratamentos parcelados em nov. e mar.

Constatou-se de maneira geral, menores produções de matéria seca e menor conteúdo de nutrientes.

Haag e Dechen (1994), em uma revisão realizada, encontraram-se as quantidades de N, P e Ca para produção de $1.000 \mathrm{~kg}$ de MS de Panicum maximum cv. Makueni de 1,$07 ; 0,1$ e $0,53 \mathrm{~g} \cdot \mathrm{m}^{-2}$, respectivamente. 


\subsection{Brachiaria humidicola}

\subsubsection{Produção de forragem}

Os resultados da produção de matéria seca $\left(\mathrm{g} \cdot \mathrm{m}^{-2}\right)$ da parte aérea de Brachiaria humidicola são apresentados na Tabela 14

Tabela 14. Produção de matéria seca $\left(\mathrm{g} \cdot \mathrm{m}^{-2}\right)$ da parte aérea de Brachiaria humidicola, em função dos períodos e épocas de aplicação de nitrogênio (média de nove repetições).

\begin{tabular}{|c|c|c|c|c|c|}
\hline \multirow{3}{*}{ Períodos ${ }^{(1)}$} & \multicolumn{5}{|c|}{ Épocas $^{(1)}$} \\
\hline & $\begin{array}{l}\text { Aplicação Total } \\
\text { (Novembro) }\end{array}$ & \multicolumn{2}{|c|}{$\begin{array}{c}\text { Parcelamento } \\
\text { (1/2 Nov. e 1/2 Mar.) }\end{array}$} & \multicolumn{2}{|c|}{$\begin{array}{c}\text { Parcelamento } \\
\text { (1/3 Nov. e 2/3 Mar.) }\end{array}$} \\
\hline & \multicolumn{5}{|c|}{$\mathrm{MS}^{(2)}$} \\
\hline "Verão" & $147,83 \mathrm{~A}$ a $92 \%$ & $135,29 \mathrm{~A} a$ & $83 \%$ & $138,71 \mathrm{~A} a$ & $78 \%$ \\
\hline "Inverno" & $12,40 \mathrm{~B} \mathrm{~b}$ & $27,81 \mathrm{~A} \mathrm{~b}$ & $17 \%$ & $37,25 \mathrm{~A} \mathrm{~b}$ & $22 \%$ \\
\hline Anual & 160,23 & 163,10 & & 175,96 & \\
\hline
\end{tabular}

C.V. (\%): $\quad 20,37$

(1) Médias de periodos e épocas, seguidas de mesma letra maiúscula (linha) e minúscula (coluna), respectivamente, não diferemtrentre si pelo teste t-Student ao nivel de 0,05 de probabilidade.

(2) Transformação da variável $=$ Produçāo de matéria seca $=\log (x)$

Para a produção de matéria seca (Tabela 15) observou-se efeito $(P<0,05)$ da interação entre os periodos e épocas de aplicação do fertilizante. Porém, no que concerne aos períodos, a produção da matéria seca foi maior no "verão" do que no "inverno", sendo que a aplicação total diferiu em relação aos demais tratamentos.

Na produção de matéria seca, verificou-se a diferença marcante entre periodos, tanto o "verão", quanto "inverno" apresentaram um aumento na produção de matéria seca à medida que a quantidade de adubo foi parcelada

A distribuição da produção de Brachiaria humidicola foi semelhante aos valores obtidos por Pedreira e Mattos (1981) que, avaliando a produção estacional de 25 capins, relataram que a espécie Brachiaria decumbens cv. Australiano apesar de bastante produtiva no "verão", teve no "inverno" somente $12 \%$ do total $\left(1.450 \mathrm{~g} \cdot \mathrm{m}^{-2}\right)$.

De acordo com Dias Filho (1983), são baixos os requerimentos externos de $\mathrm{N}$ em Brachiaria humidicola para a produção de matéria seca quando comparada à $B$. decumbens e ruziziensis, apresentando maiores taxas de produção de matéria seca 
com a menor dose de $\mathrm{N}$ aplicada (25 $\mathrm{kg}$ de $\mathrm{N} / \mathrm{ha}$ ), assim como observado neste trabalho, onde a aplicação de $50 \mathrm{~kg} \cdot \mathrm{ha}^{-1}$ de $\mathrm{N}$, proporcionou produção de matéria seca igual a aplicação de $150 \mathrm{~kg} \cdot \mathrm{ha}^{-1}$.

Maiores produções de matéria seca foram obtidas nos tratamentos onde se parcelou as aplicações de $N$, principalmente naquele em que $2 / 3$ da dose foi aplicada em março, enquanto que Leite et. al (1981), conduzindo trabalho em Planaltina - DF utilizando quatro cultivares de Brachiaria, adubadas com diferentes doses de nitrogênio $(0,5,10,25$ e $50 \mathrm{~kg}$ de $\mathrm{N} / \mathrm{ha}$, após cada um dos 11 cortes) obtiveram maiores produções em todas as quantidades aplicadas com exceção da dose zero.

Gonçalves et al. (1990), conduzindo experimento de Brachiaria humidicola em Rondônia, obtiveram rendimentos de matéria seca de 1.120 e $525 \mathrm{~g} \cdot \mathrm{m}^{-2}$, respectivamente para a estação chuvosa e seca, apresentando menores diferenças de produção entre "verão" e "inverno" quando comparado aos resultados do presente trabalho, pois a época seca no Estado de São Paulo em geral, possui como característica, menores índices de pluviosidade e temperaturas médias que na região de Rondônia.

\subsubsection{Composição bromatológica}

Os resultados de proteína bruta $\left(\mathrm{g} \cdot \mathrm{kg}^{-1}\right)$ na matéria seca da parte aérea de Brachiaria humidicola estão apresentados na Tabela 15.

Tabela 15. Teores de proteina bruta $\left(\mathrm{g} \cdot \mathrm{kg}^{-1}\right)$ na matéria seca da parte aérea de Brachiaria humidicola em função dos períodos e épocas de aplicação de nitrogênio (média de nove repetições).

\begin{tabular}{|c|c|c|c|c|c|c|}
\hline \multirow{3}{*}{$\begin{array}{l}\text { Períodos (1) } \\
\text { "Verão" }\end{array}$} & \multicolumn{6}{|c|}{ Épocas ${ }^{(1)}$} \\
\hline & \multicolumn{2}{|c|}{$\begin{array}{l}\text { Aplicação Total } \\
\text { (Novembro) }\end{array}$} & \multicolumn{2}{|c|}{$\begin{array}{c}\text { Parcelamento } \\
\text { (1/2 Nov. e 1/2 Mar.) }\end{array}$} & \multicolumn{2}{|c|}{$\begin{array}{c}\text { Parcelamento } \\
\text { (1/3 Nov. e 2/3 Mar.) }\end{array}$} \\
\hline & $77,91^{(2)} \mathrm{A} a$ & $51 \%$ & $76,77 \mathrm{~A} \mathrm{~b}$ & $47 \%$ & $81,15 \mathrm{~A} \mathrm{~b}$ & $49 \%$ \\
\hline "Inverno" & $76,13 \mathrm{~B} \mathrm{~b}$ & $49 \%$ & $86,45 \mathrm{~A} a$ & $53 \%$ & $84,55 \mathrm{~A} a$ & $51 \%$ \\
\hline Anual & 154,04 & & 163,22 & & 165,70 & \\
\hline C.V. (\%): & 7,07 & & & & & \\
\hline
\end{tabular}


Para PB, verificou-se efeito da interação entre épocas e periodo utilizados $(P<0,05)$. Os teores de PB $\left(\mathrm{g} \cdot \mathrm{kg}^{-1}\right)$ mantiveram-se constantes sem efeitos significativos $(P>0,05)$ no período de "verão", enquanto no "inverno" apenas diferindo na aplicação total em nov. (Tabela 15).

De acordo com Norton (1982) os teores acima obtidos, deixam a desejar no atendimento as necessidades nutricionais dos animais tido como o minimo de $150 \mathrm{~g}$ PB $\mathrm{kg}^{-1}$ exigido para animais lactantes ou em crescimento e satisfatória para ovinos e bovinos que reduzem o consumo voluntário quando a concentração de PB é inferior a $80-100 \mathrm{~g} \mathrm{~kg}^{-1}$. Ressaltando que, a deficiência protéica em ruminantes reduz a atividade da microflora ruminal e portanto a taxa de digestão da celulose (Forbes, 1995).

Undersander e Hutcheson (1984) buscando obter respostas sobre as mudanças estacionais na composição de gramíneas nativas em experimento (19781981) conduzido no Texas - EUA, mostraram que houve uma tendência estacional durante o ano, e que em 1978, as espécies tenderam a alcançar niveis mínimos de PB durante $o$ crescimento na primavera e mantendo-se ao longo do ano, enquanto que no presente trabalho, os menores teores de proteina bruta ocorreram no verão nos tratamentos com aplicação parcelada e, no de aplicação total, o menor teor foi observado no inverno.

Assim como os teores de PB obtidos de Brachiaria humidicola ficaram aquém do mínimo recomendado, em qualquer das doses e parcelamentos estudados, tanto no "verão" como no "inverno", Cardoso et al. (1997) e Bergamaschine et al (1998), obtiveram resultados de que o conteúdo de PB foi baixo, tanto na estação seca $\left(35 \mathrm{~g} \cdot \mathrm{kg}^{-1}\right)$, quanto na chuvosa (48 g. $\left.\mathrm{kg}^{-1}\right)$, caracterizando por serem, inferiores do que 0 requerido para $\circ$ gado bovino $\left(>70 \mathrm{~g} . \mathrm{kg}^{-1}\right)$. Confirmado por Souza Filho et al. (1992), que concluiram que a Brachiaria humidicola possui potencial forrageiro superior ao das pastagens nativas (gêneros Axonopus, Andropogon, Eragrostis, Trachypogon, Paspalum e Aristida), apenas em função da maior capacidade de produção de forragem. O teor de PB apenas na época out.-dez., foi igual estatisticamente nas tres idades de corte, tendendo a decrescer com o aumento das mesmas, sendo que em nenhuma das idades o valor mínimo de PB $\left(80 \mathrm{~g} \mathrm{~kg}^{-1}\right.$ na MS), para bovinos de corte foi atingido 


\subsubsection{Composição mineral}

Seria desejável que a composição mineral da forragem ingerida fosse igual à exigência dos animais em pastejo. Evidentemente, isso raramente ocorre ao mesmo tempo para todos os elementos essenciais, mesmo nos casos nos quais são feitas adubações com todos os elementos devidamente equilibrados para manter as exigências das plantas forrageiras. As principais razões são que os niveis de minerais exigidos pelas forragens não são sempre os mesmos exigidos pelos animais. (Boin, 1986).

A Tabela 16 apresenta os teores de N, P, K, Ca e Mg em função da interação significativa $(P<0,05)$ entre períodos e épocas de aplicação de nitrogênio e também diferença significativa $(P<0,05)$ nas concentrações, entre os periodos estudados.

Tabela 16. Teores de $\mathrm{N}, \mathrm{K}, \mathrm{Ca}$ e $\mathrm{Mg}\left(\mathrm{g} \cdot \mathrm{kg}^{-1}\right)$ na matéria seca da parte aérea de Brachiaria humidicola em função dos períodos e épocas de aplicação de nitrogênio (média de nove repetições).

\begin{tabular}{|c|c|c|c|c|c|}
\hline \multirow[b]{2}{*}{$\begin{array}{c}\text { Nutrientes } \\
\left(\mathrm{g} \cdot \mathrm{kg}^{-1}\right)\end{array}$} & \multirow[b]{2}{*}{ Periodos $^{(1)}$} & \multicolumn{3}{|c|}{ Épocas ${ }^{(1)}$} & \multirow[b]{2}{*}{$\begin{array}{l}\text { C.V. } \\
\text { (\%) }\end{array}$} \\
\hline & & $\begin{array}{l}\text { Aplicação total } \\
\text { (Nov.) }\end{array}$ & $\begin{array}{c}\text { Parcelamento } \\
\text { (1/2 Nov. e 1/2 Mar.) }\end{array}$ & $\begin{array}{c}\text { Parcelamento } \\
\text { (1/3 Nov. e 2/3 Mar.) }\end{array}$ & \\
\hline & "Verão" & $12,59 \mathrm{~A} a$ & $12,50 \mathrm{Ab}$ & $13,25 \mathrm{Ab}$ & \\
\hline$N^{(2)}$ & "Inverno" & $12,44 \mathrm{~B} \mathrm{~b}$ & $14,27 \mathrm{~A} \mathrm{a}$ & $13,93 \mathrm{Aa}$ & 10,65 \\
\hline$K^{(2)}$ & $\begin{array}{l}\text { "Verão" } \\
\text { "Inverno" }\end{array}$ & $\begin{array}{c}16,70 \mathrm{~A} \mathrm{a} \\
8,59 \mathrm{~B} \mathrm{~b}\end{array}$ & $\begin{array}{l}16,34 \mathrm{~A} \mathrm{a} \\
11,49 \mathrm{~A} \mathrm{~b}\end{array}$ & $\begin{array}{l}16,60 \mathrm{~A} \mathrm{a} \\
11,58 \mathrm{~A} \mathrm{~b}\end{array}$ & 13,78 \\
\hline $\mathrm{Ca}^{(2)}$ & $\begin{array}{l}\text { "Verão" } \\
\text { "Inverno" }\end{array}$ & $\begin{array}{l}2,59 \mathrm{~A} \mathrm{~b} \\
4,82 \mathrm{~A} \mathrm{a}\end{array}$ & $\begin{array}{l}2,64 \mathrm{~A} \mathrm{~b} \\
4,47 \mathrm{~B} \mathrm{a}\end{array}$ & $\begin{array}{l}2,48 \mathrm{~B} \mathrm{~b} \\
4,22 \mathrm{C} \mathrm{a}\end{array}$ & 20,20 \\
\hline $\mathrm{Mg}^{(2)}$ & $\begin{array}{l}\text { "Verão" } \\
\text { "Inverno" }\end{array}$ & $\begin{array}{l}1,91 \mathrm{~A} \mathrm{~b} \\
2,60 \mathrm{~A} \mathrm{a}\end{array}$ & $\begin{array}{l}1,82 \mathrm{~A} \mathrm{~b} \\
2,74 \mathrm{~A} \mathrm{a}\end{array}$ & $\begin{array}{l}1,83 \mathrm{Ab} \\
2,71 \mathrm{~A} \mathrm{a}\end{array}$ & 8,35 \\
\hline
\end{tabular}

\footnotetext{
"Médias de períodos e épocas, seguidas de mesma letra maiúscula (linha) e minúscula (coluna), respectivamente, não diferementre si pelo teste t-Student ao nivel de 0,05 de probabilidade.

(2) Transformação das variáveis $N=1 / \sqrt{ } x ; K=\sqrt{ } x ; C a=\log (x)$ e $M g=\log (x)$.
} 


\section{Nitrogênio}

Os resultados para os teores de $\mathrm{N}\left(\mathrm{g} \cdot \mathrm{kg}^{-1}\right)$ na matéria seca da parte aérea de Brachiaria humidicola encontram-se reunidos na Tabela 16.

Em relação aos teores de $\mathrm{N}$ obtidos, observou-se que os mesmos, diferiram entre as épocas dentro do período de "inverno" e "verão", sendo que no verão, os maiores teores ocorreram nas épocas de aplicação parcelada e, no "inverno", o maior teor ocorreu com aplicação total de nitrogênio $\left(12,44 \mathrm{~g} \cdot \mathrm{kg}^{-1}\right)$.

Os teores de $\mathrm{N}$ ficaram abaixo das concentrações requeridas para a planta, porém satisfatórias para bovinos de corte, sendo estas $17,0 \mathrm{~g} . \mathrm{kg}^{-1}$ de acordo com Malavolta (1986) e > 12,8g. $\mathrm{kg}^{-1}$ por Gallo et al.(1974).

\section{Fósforo}

Os resultados para os teores de $\mathrm{P}\left(\mathrm{g} \cdot \mathrm{kg}^{-1}\right)$ na matéria seca da parte aérea de Brachiaria humidicola encontram-se reunidos na Tabela 17 e 18.

Tabela 17. Teores de $\mathrm{P}\left(\mathrm{g} \cdot \mathrm{kg}^{-1}\right)$ na matéria seca da parte aérea de Brachiaria humidicola em função dos periodos e épocas de aplicação de nitrogênio (média de nove repetições).

\begin{tabular}{cccc}
\hline & \multicolumn{3}{c}{ Épocas $^{(1)}$} \\
\cline { 2 - 4 } Periodos" & $\begin{array}{c}\text { Aplicação Total } \\
\text { (Novembro) }\end{array}$ & $\begin{array}{c}\text { Parcelamento } \\
(1 / 2 \text { Nov. e 1/2 Mar. })\end{array}$ & $\begin{array}{c}\text { Parcelamento } \\
\text { (1/3 Nov. e 2/3 Mar.) }\end{array}$ \\
\cline { 2 - 4 } "Verão " & $2,38^{(2)} \mathrm{B} \mathrm{a}$ & $2,62 \mathrm{~A} \mathrm{a}$ & $2,48 \mathrm{~B} \mathrm{a}$ \\
"Inverno" & $1,73 \mathrm{~A} \mathrm{~b}$ & $1,71 \mathrm{AB} \mathrm{b}$ & $1,62 \mathrm{~B} \mathrm{~b}$ \\
\hline C.V. (\%): & 10,22 & & \\
\hline
\end{tabular}

(1) Médias de periodos e épocas, seguidas de mesma letra maiúscula (linha) e minúscula (coluna), respectivamente, nāo diferementre si pelo teste $t$-Student ao nivel de 0.05 de probabilidade.

(2) Transformação da variável $P=\sqrt{ } x$

Os teores de $\mathrm{P}$ variaram dentro de cada um dos períodos, tendo no "verão" apresentado o maior teor $\left(2,62 \mathrm{~g} . \mathrm{kg}^{-1}\right)$ referente ao parcelamento de $1 / 2 \mathrm{em}$ nov. e $1 / 2$ em mar. e no "inverno" o menor teor $\left(1,62 \mathrm{~g} \cdot \mathrm{kg}^{-1}\right)$ apresentado pelo parcelamento $1 / 3$ em nov. e 2/3 em mar no período de "inverno". (Tabela 17).

Além do efeito de interação periodos e épocas, houve efeito significativo $(P<0,05)$ para a interação doses e épocas (Tabela 18). 
Tabela 18. Teores de $P\left(\mathrm{~g} \cdot \mathrm{kg}^{-1}\right)$ na matéria seca da parte aérea de Brachiaria humidicola em função de doses de adubação nitrogenada e épocas de aplicação de nitrogênio (média de nove repetições).

\begin{tabular}{cccc}
\hline \multirow{2}{*}{$\begin{array}{c}\text { Doses }^{(1)} \\
(\mathrm{kg} \mathrm{de} \mathrm{N})\end{array}$} & $\begin{array}{c}\text { Aplicação Total } \\
\text { (Novembro) }\end{array}$ & $\begin{array}{c}\text { Épocas }^{(1)} \\
\text { (1/2 Nov. e 1/2 Mar.) }\end{array}$ & $\begin{array}{c}\text { Parcelamento } \\
\text { (1/3 Nov. e 2/3 Mar.) }\end{array}$ \\
\hline $50^{(2)}$ & $2,04^{(2)} \mathrm{B} \mathrm{a}$ & $2,34 \mathrm{~A} \mathrm{a}$ & $2,09 \mathrm{~B} \mathrm{a}$ \\
100 & $2,03 \mathrm{~A} \mathrm{a}$ & $2,06 \mathrm{~A} \mathrm{~b}$ & $2,01 \mathrm{~A} \mathrm{a}$ \\
150 & $2,09 \mathrm{~A} \mathrm{a}$ & $2,10 \mathrm{~A} \mathrm{~b}$ & $2,04 \mathrm{~A} \mathrm{a}$ \\
\hline
\end{tabular}

C.V. (\%): $\quad 10,22$

\footnotetext{
"Médias de doses e épocas, seguidas de mesma letra maiúscula (linha) e minúscula (coluna), respectivamente, não diferementre si pelo teste t-Student ao nível de 0.05 de probabilidade.

(2) Transformação da variável $P=v x$
}

Os teores de $\mathrm{P}$ variaram de acordo com a dose dentro de cada época, porém diferindo significativamente somente a dose 50 , para o parcelamento $1 / 2$ em novembro e $1 / 2$ em março, apresentando o maior teor $\left(2,34 \mathrm{~g} \cdot \mathrm{kg}^{-1}\right)$, o que coincidiu, quando fez-se a comparação entre doses dentro da mesma época.

Os teores obtidos na interação doses e épocas encontraram-se no mínimo exigido quando comparados aos teores adequados em relação à concentração média na planta e à exigência de bovinos, $2-4 \mathrm{~g} \cdot \mathrm{kg}^{-1}$ e $1,8-4,3 \mathrm{~g} \cdot \mathrm{kg}^{-1}$, respectivamente, (Gallo et al. 1974), e do teor médio de gramíneas no Estado de São Paulo apresentado por Malavolta et al. (1986) $\left(2,1 \mathrm{~g} \mathrm{~kg}^{-1}\right)$.

Assim como ocorreram menores teores de P no período de "inverno" na matéria seca, Souza Filho (1992) comparando pastagens nativas com Brachiaria humidicola durante quatro épocas de corte, obteve teores de $P$ que variaram significativamente em função dos períodos de crescimento .A tendência foi de decréscimo nos períodos 1 (jan.-mar.), 2 (abr.-jun.) e 3 (jul.-set.) e acréscimo no período 4 (out.-dez.).

Os teores de $\mathrm{P}$, tanto no período de "verão" quando no de "inverno", estiveram bem acima do requerimento nutricional para $\mathrm{P}$ nos tecidos de Brachiaria humidicola que, segundo Falesi e Veiga (1986), está em tomo de $0,8 \mathrm{~g} \cdot \mathrm{kg}^{-1}$, semelhante aos teores encontrados por Italiano e Silva (1986) que variaram de 1,2 a $0,7 \mathrm{~g} . \mathrm{kg}^{-1}$ respectivamente, dos 14 aos 56 dias de crescimento.

Matos et al. (1987), determinando teores $P$ do capim quicuio-da-amazônia (Brachiaria humidicola) em tres idades de corte, em Belém - PA, observou que os 
teores ficaram abaixo do nivel crítico interno na planta $\left(2,6 \mathrm{~g} \cdot \mathrm{kg}^{-1}\right)$, neste caso, os teores obtidos neste experimento, também estariam abaixo do nivel crítico.

\section{Potássio}

De acordo com a Tabela 16 , para os teores de $\mathrm{K}\left(\mathrm{g} \cdot \mathrm{kg}^{-1}\right)$ não houve diferença significativa $(P>0,05)$ no "verão" entre as épocas de aplicação de nitrogênio, apesar dos mesmos terem sido superiores quando comparados ao periodo de "inverno", cujo menor teor foi atribuido ao tratamento de aplicação total em novembro $\left(8,59 \mathrm{~g} \cdot \mathrm{kg}^{-1}\right)$.

Em comparação com os requerimentos necessários para atender as exigências nutricionais da planta, os teores de $K$ não estão compreendidos no intervalo de concentração considerada normal na planta (12-28g. $\left.\mathrm{kg}^{-1}\right)$ citado por Gallo et al. (1974), porém atingindo a concentração adequada para a necessidade de bovinos $(1,8$ $4,3 \mathrm{~g} \cdot \mathrm{kg}^{-1}$ ), e condizendo com a recomendação dada pelo NRC (1996) para as algumas categorias de bovinos de corte $\left(6,0 \mathrm{~g} \cdot \mathrm{kg}^{-1}\right)$.

De acordo com Toledo (1986), o teor a presentado para requerimento nutricional em Brachiaria humidicola é de $7,4 \mathrm{~g} \cdot \mathrm{kg}^{-1}$, portanto, os teores apresentados neste trabalho estão acima do mínimo recomendado.

Undersander e Hutcheson (1984) buscando obter respostas sobre as mudanças estacionais na composição de gramineas nativas, confirmaram a variação sazonal sobre os teores de $K$, obtendo concentrações altas nos meses de junho, julho e agosto, variando de 3,7 a 5,0g. $\mathrm{kg}^{-1}$ em 1978 e superiores a $6,0 \mathrm{~g} \cdot \mathrm{kg}^{-1}$ em 1979 e 1981. Sendo que tal variação estacional não se repetiu segundo os dados apresentados para os teores de $\mathrm{K}$.

\section{Cálcio}

Conforme apresentado na Tabela 16, os teores de "inverno" em relação a cada época, foram aproximadamente o dobro do "verão". O maior teor $\left(4,82 \mathrm{~g} \cdot \mathrm{kg}^{-1}\right)$ encontrase na época de aplicação total em nov, no periodo de "inverno", seguido a época 1/2 nov. e 1/2 mar. e por último 1/3 novembro e 2/3 março. Já, no período de "verão", o menor teor ocorre em 1/3 nov. e 2/3 mar., sendo os demais iguais.

Segundo Gallo (1974), em geral, os teores apresentados em ambos os periodos estão em concordância com às exigências nutricionais considerando a concentração normal para a planta $\left(2,0-4,0 \mathrm{~g} \cdot \mathrm{kg}^{-1}\right)$, assim como a concentração 
adequada para bovinos $\left(1,8-6,0 \mathrm{~g} \cdot \mathrm{kg}^{-1}\right)$ concomitantemente, com a recomendação descrita pelo NRC (1996) de 1,9-7,3g. $\mathrm{kg}^{-1}$ para algumas categorias de bovinos de corte. Contudo, de acordo com Malavolta (1986), apenas o maior teor de $\mathrm{Ca}$ relacionado ao período de "invemo" conseguiu atingir a concentração mineral recomendada.

Thomas e Andrade (1984), avaliando o desempenho agronômico de cinco gramíneas, dentre elas, Brachiaria humidicola, submetidas à presença e ausência de leguminosas, encontraram teor de Ca superior $\left(5,0 \mathrm{~g} \cdot \mathrm{kg}^{-1}\right)$ em relação a Brachiaria decumbens e Brachiaria ruziziensis 2,4 e $3,6 \mathrm{~g} \cdot \mathrm{kg}^{-1}$, respectivamente, durante a estação chuvosa, teores uma pouco maiores que mostrados na Tabela 16.

Os teores de $\mathrm{Ca}$ encontrados no período de verão foram bastante semelhantes aos teores de 2,65g. $\mathrm{kg}^{-1}$ em Brachiaria decumbens e $2,2 \mathrm{~g} \cdot \mathrm{kg}^{-1}$ para Brachiaria humidicola obtida por Toledo (1986).

Vários trabalhos publicados por diversos autores, citados por Costa (1997), em revisão de literatura realizada, têm consistentemente mostrado que, os teores de $\mathrm{Ca}$ em Brachiaria humidicola, geralmente, são inferiores aos de Panicum maximum, Brachiaria decumbens, B. ruziziensis e Andropogon gayanus, principalmente em estádios mais avançados de crescimento.

\section{Magnésio}

Os valores encontrados para Mg no período de "inverno" foram superiores em relação aos do período de "verão", apesar dos resultados encontrados dentro de cada período não deferiram (apresentados na Tabela 16).

Os teores de $\mathrm{Mg}$ obtidos foram maiores ou acima do limite superior considerado normal para as plantas por Gallo et al. (1974) $\left(2,6 \mathrm{~g} \mathrm{~kg}^{-1}\right)$, o que também foi observado por Malavolta et al. (1986) $\left(2,7 \mathrm{~g} \cdot \mathrm{kg}^{-1}\right)$ e estando de acordo com às exigências recomendadas pelo NRC (1996). Para (1986) o teor encontrado para Mg em Brachiaria humidicola foi de $1,6 \mathrm{~g} \cdot \mathrm{kg}^{-1}$, estando dessa maneira de acordo. 


\section{Enxofre}

Observou-se efeitos significativos $(P<0,05)$ isolados, tanto para épocas quanto para os períodos, apresentados a seguir nas Tabelas 20 e 21, respectivamente.

Tabela 20. Teores de S na matéria seca da parte aérea de Brachiaria humidicola em função das épocas de aplicação de nitrogênio (média de nove repetições).

\begin{tabular}{ll}
\hline \multicolumn{1}{c}{ Épocas $^{(1)}$} & $\mathrm{S}\left(\mathrm{g}^{\mathrm{kg}} \mathrm{kg}^{-1}{ }^{(2)}\right.$ \\
\hline Aplicação Total (Novembro) & $1,35 \mathrm{~A}$ \\
Parcelamento (1/2 Nov. e 1/2 Mar.) & $1,25 \mathrm{BC}$ \\
Parcelamento (1/3 Nov. e 2/3 Mar.) & $1,24 \mathrm{C}$ \\
C.V. (\%) & 6,94 \\
(1) Médias de épocas seguidas de mesma letra maiúscula (coluna) não diferem entre si pelo teste t-Student ao nivel de \\
0.05 de probabilidade. \\
${ }^{(2)}$ Transformação da variável $\mathrm{S}=1 / \sqrt{\mathrm{x}}$
\end{tabular}

Tabela 21. Teores de S na matéria seca da parte aérea de Brachiaria humidicola em função dos periodos estacionais (média de nove repetições).

\begin{tabular}{|c|c|}
\hline Períodos $^{(1)}$ & $\mathrm{S}\left(\mathrm{g} \cdot \mathrm{kg}^{-1}\right)^{(2)}$ \\
\hline "Verão" & $1,49 \mathrm{~A}$ \\
\hline "Inverno" & $1,47 \mathrm{~B}$ \\
\hline C.V. (\%) & 6,94 \\
\hline
\end{tabular}

(1) Médias de periodos seguidas de mesma letra maiúscula (coluna) não diferem entre si pelo teste t-Student ao nivel de 0,05 de probabilidade.

(2) Transformação da variável $\mathrm{S}=1 / \sqrt{ } \mathrm{x}$

O maior teor encontrado para $S$ foi atribuido ao tratamento com aplicação total em novembro $\left(1,35 \mathrm{~g} \cdot \mathrm{kg}^{-1}\right)$, estando acima da concentração média (1 $\left.\mathrm{g} \cdot \mathrm{kg}^{-1}\right)$ observada por Malavolta et al. (1986) em gramíneas no Estado de São Paulo. Porém, Gallo et al. (1974) consideram como concentração normal de $S$ nas plantas 1 a $3 \mathrm{~g} \mathrm{~kg}^{-1}$. De acordo com o NRC (1996), mesmo o maior teor encontrado em Brachiaria humidicola não atingiu a concentração recomendada para bovinos de corte $\left(1,5 \mathrm{~g} \cdot \mathrm{kg}^{-1}\right)$ (Tabela 20).

$\mathrm{Na}$ Tabela 21, houve efeito significativo para periodos $(P<0,05)$, onde os teores de $S$ mostraram-se acima das concentrações recomendadas. A causa para a diminuição observada nos teores pode ser devida ao efeito de diluição destes com o aumento da produção de matéria seca, como observado por Gomide (1978). 


\section{Relações entre nutrientes}

Algumas das principais relações entre nutrientes N/S e Ca/P, observadas na matéria seca da parte aérea de Brachiaria humidicola são apresentadas nas Tabelas 22 a 25.

Tabela 22. Relação entre os nutrientes N/S obtidos na matéria seca da parte aérea de Brachiaria humidicola, em função dos periodos e épocas de aplicação de nitrogênio (média de nove repetições).

\begin{tabular}{cccc}
\hline & \multicolumn{4}{c}{ Épocas $^{(1)}$} \\
\cline { 2 - 4 } Períodos" & $\begin{array}{c}\text { Aplicação Total } \\
\text { (Novembro) }\end{array}$ & $\begin{array}{c}\text { Parcelamento } \\
(1 / 2 \text { Nov. e 1/2 Mar. })\end{array}$ & $\begin{array}{c}\text { Parcelamento } \\
(1 / 3 \text { Nov. e 2/3 Mar. })\end{array}$ \\
\hline "Verão " & 11,48 B a & $11,83 \mathrm{AB} \mathrm{a}$ & $12,05 \mathrm{~A}$ a \\
"Inverno" & $8,33 \mathrm{~B} \mathrm{~b}$ & $10,20 \mathrm{~A}$ b & $10,26 \mathrm{~A} \mathrm{~b}$ \\
\hline C.V. (\%): & 29,65 & & \\
\hline
\end{tabular}

77 Médias de períodos e épocas, seguidas de mesma letra maiúscula (linha) e minúscula (coluna), respectivamente, não diferemtentre si pelo teste t-Student ao nivel de 0,05 de probabilidade.

Entre os períodos estudados, observou-se que houve diferença significativa na relação N/S $(P<0,05)$ sendo os resultados encontrados no "verão" superiores em relação ao "inverno" (Tabela 22). No período de "verão" o parcelamento $1 / 3$ em novembro e 2/3 em março apresentou a maior relação $(12,05 / 1)$ enquanto que o tratamento com aplicação total em novembro a menor $(11,48 / 1)$. Para o período de "inverno" também o tratamento de aplicação total apresentou a menor relação $(8,33 / 1)$.

Tabela 23. Relação entre os nutrientes N/S obtidos na matéria seca da parte aérea de Brachiaria humidicola, em função das doses de adubação nitrogenada e épocas de aplicação de nitrogênio (média de nove repetições).

\begin{tabular}{cccc}
\hline Doses $^{(1)}$ & \multicolumn{3}{c}{ Épocas $^{(1)}$} \\
\cline { 2 - 3 }$($ kg de N $)$ & $\begin{array}{c}\text { Aplicação Total } \\
\text { (Novembro })\end{array}$ & $\begin{array}{c}\text { Parcelamento } \\
(1 / 2 \text { Nov. e 1/2 Mar. })\end{array}$ & $\begin{array}{c}\text { Parcelamento } \\
(1 / 3 \text { Nov. e 2/3 Mar. })\end{array}$ \\
\hline $50^{(2)}$ & $10,28 \mathrm{~A} \mathrm{a}$ & $11,01 \mathrm{~A} \mathrm{a}$ & $10,49 \mathrm{~A} \mathrm{~b}$ \\
100 & $9,56 \mathrm{~B} \mathrm{a}$ & $11,03 \mathrm{~A} \mathrm{a}$ & $11,77 \mathrm{~A} \mathrm{a}$ \\
150 & $9,88 \mathrm{~B} \mathrm{a}$ & $10,99 \mathrm{~A} \mathrm{a}$ & $11,87 \mathrm{~A} \mathrm{a}$ \\
\hline C.V. $(\%):$ & 29,65 & &
\end{tabular}

\footnotetext{
"Médias de doses e épocas, seguidas de mesma letra maiúscula (linha) e minúscula (coluna), respectivamente, não diferementre si pelo teste t-Student ao nivel de 0,05 de probabilidade.
} 
Verificou-se diferença significativa para doses 100 e $150 \mathrm{~kg}$ de $\mathrm{N}$ entre as épocas estudadas. As menores relações N/S foram atribuídas à época de aplicação total em novembro $(9,56 / 1$ e 9,88/1), para ambas as doses, respectivamente.

Quando fez-se a comparação entre doses dentro da mesma época, observouse que apenas a relação N/S (10,49/1), na dose $50 \mathrm{~kg}$ de $\mathrm{N}$ com época de parcelamento $1 / 3$ em novembro e $2 / 3$ em março, diferiu significativamente das demais.

De modo geral, os resultados encontrados nas Tabelas 23 e 24 , as relações N/S estiveram abaixo de 12/1 a 15/1 consideradas por Follet e Wilkinson (1995) para a máxima produção vegetal e inferiores a 14/1, valor no qual a relação tende a se estabilizar quando as gramíneas atingem a maturidade, segundo Vitti e Novaes (1986).

Segundo Church (1993), a relação N/S ideal é 15/1 para bovinos e 10/1 a 12/1 para ovinos e, de acordo com Van Soest (1994), 12/1 para os microrganismos ruminais. Assim, a relação N/S obtida neste trabalho só atenderia a exigência de ovinos nos tratamentos que envolveram os parcelamentos.

A baixa relação N/S observada deve-se, em parte, a concentrações de $S$ encontradas acima da média das exigências animais.

Tabela 24. Relação entre os nutrientes Ca/P obtidos na matéria seca da parte aérea de Brachiaria humidicola, em função dos períodos estacionais (média de nove repetições).

\begin{tabular}{ll}
\hline \multicolumn{1}{c}{ Períodos $^{(1)}$} & $\mathrm{Ca} / \mathrm{P}^{(2)}$ \\
\hline "Verão" & $1,06 \mathrm{~B}$ \\
"Inverno" & $2,91 \mathrm{~A}$ \\
$\mathrm{C.V} .(\%)$ & 12,57 \\
\hline Médias de periodos seguidas de mesma letra maiúscula (coluna) não diferem entre si pelo teste t-Student ao nivel de \\
0,05 de probabilidade. \\
\multicolumn{2}{|c|}{ A relação Ca/P em função dos períodos foi significativa $(\mathrm{P}<0,05)$, destacando- }
\end{tabular}
se a maior relação no "invemo" do que no "verão". (Tabela 24)

Segundo Souza (1986b), elementos como o cálcio são praticamente imóveis, portanto, aumentam no tecido vegetal à medida que a planta envelhece. Plantas novas tem relativamente mais fósforo e menos cálcio, enquanto plantas velhas apresentam uma relação contrária. 
Tabela 25. Relação entre os nutrientes $\mathrm{Ca} / \mathrm{P}$ calculadas na matéria seca da parte aérea de Brachiaria humidicola, em função das doses e épocas de aplicação de nitrogênio (média de nove repetições).

\begin{tabular}{cccc}
\hline Doses $^{(1)}$ & \multicolumn{3}{c}{ Épocas $^{(1)}$} \\
\cline { 2 - 4 }$(\mathrm{kg})$ & $\begin{array}{c}\text { Aplicação Total } \\
\text { (Novembro) }\end{array}$ & $\begin{array}{c}\text { Parcelamento } \\
(1 / 2 \mathrm{Nov} . \mathrm{e} 1 / 2 \mathrm{Mar} .)\end{array}$ & $\begin{array}{c}\text { Parcelamento } \\
(1 / 3 \mathrm{Nov} . \text { e 2/3 Mar. })\end{array}$ \\
\hline $50^{(2)}$ & $2,10 \mathrm{~A} \mathrm{a}$ & $1,81 \mathrm{C} \mathrm{b}$ & $1,92 \mathrm{~B} \mathrm{a}$ \\
100 & $2,43 \mathrm{~A} \mathrm{a}$ & $2,13 \mathrm{~A} \mathrm{a}$ & $1,99 \mathrm{~A} \mathrm{a}$ \\
150 & $2,06 \mathrm{~A} \mathrm{a}$ & $1,93 \mathrm{~A} \mathrm{a}$ & $1,80 \mathrm{~A} \mathrm{a}$ \\
\hline C.V. (\%): & 29,65 &
\end{tabular}

(1) Médias de doses e épocas, seguidas de mesma letra maiúscula (linha) e minúscula (coluna), respectivamente, não diferemrentre si pelo teste t-Student ao nivel de 0,05 de probabilidade.

(2) Transformação da variável $\mathrm{Ca} / \mathrm{P}=(\mathrm{Ca} / \mathrm{P})^{-04}$

Para a relação $\mathrm{Ca} / \mathrm{P}$ as épocas de aplicação apenas diferiram significativamente $(P<0,05)$ na dose $50 \mathrm{~kg}$ de $\mathrm{N}$, apresentando a aplicação total em nov. maior relação $(1,81 / 1)$, seguida dos parcelamentos $1 / 3$ em nov. e $2 / 3$ em mar. $(1,92 / 1)$ e $1 / 2$ em nov. e $1 / 2$ em mar. (1,81/1).

Segundo o NRC (1996), relações Ca/P entre 1/1 e 1/7, resultam em desempenhos similares desde que o consumo de fósforo seja suficiente para atender às exigências. Entretanto, segundo Boin (1985), quando as exigências de $P$ são atendidas, a relação $\mathrm{Ca} / \mathrm{P}$ deixa de ser menos importante.

As relações entre os elementos são muito importantes em termos de nutrição animal, notadamente a relação $\mathrm{Ca} / \mathrm{P}$ é uma das mais importantes, pois o desequilíbrio entre esses nutrientes pode causar problemas metabólicos nos animais (Vendramini, 1999).

A relação Ca/P observada na Tabela 25 , foi superior a $1 / 1$, valor mínimo este, apresentado por Wise et al. (1963), cujos resultados relataram efeitos prejudiciais ao crescimento e deficiência alimentar de bezerros, ingerindo alimentos com relação $\mathrm{Ca} / \mathrm{P}$, inferior a $1 / 1$. 


\section{Conteúdo de nutrientes}

Os conteúdos de $\mathrm{N}, \mathrm{P}$ e Ca $\left(\mathrm{g} \cdot \mathrm{m}^{-2}\right)$ na matéria seca da parte aérea do Brachiaria humidicola estão reunidas na Tabela 26 a 28.

Tabela 26. Conteúdo de $\mathrm{N}$ na matéria seca $\left(\mathrm{g} \cdot \mathrm{m}^{2}\right)$ da parte área de Brachiaria humidicola, em função das doses de adubação nitrogenada e épocas de aplicação de nitrogênio (média de nove repetições).

\begin{tabular}{|c|c|c|c|}
\hline \multirow[b]{2}{*}{ Períodos $^{(1)}$} & \multicolumn{3}{|c|}{ Épocas ${ }^{(1)}$} \\
\hline & $\begin{array}{l}\text { Aplicação Total } \\
\text { (Novembro) }\end{array}$ & $\begin{array}{c}\text { Parcelamento } \\
\text { (1/2 Nov. e 1/2 Mar.) }\end{array}$ & $\begin{array}{c}\text { Parcelamento } \\
\text { (1/3 Nov. e 2/3 Mar.) }\end{array}$ \\
\hline "Verão" & $0,04^{(2)} \mathrm{A} a$ & $0,02 \mathrm{~A} a$ & $0,03 \mathrm{~A} a$ \\
\hline "Inverno" & $0,002 \mathrm{~A} \mathrm{~b}$ & $0,007 \mathrm{BC} b$ & $0,007 \mathrm{C} \mathrm{b}$ \\
\hline
\end{tabular}

C.V. (\%): 23,01

(1) Médias de periodos e épocas, seguidas de mesma letra maiúscula (linha) e minúscula (coluna), respectivamente, nāo diferertrentre si peloteste t-Student ao nivel de 0,05 de probabilidade.

(2) Transformação da variável $\mathrm{N}=(\mathrm{N})^{-0.2}$

Verificou-se uma diferença significativa $(P<0,05)$ nos conteúdos de $N$ para períodos e entre épocas de aplicação ("inverno"), sendo a época de aplicação total em nov. apresentando valor menor $\left(0,002 \mathrm{~g} \cdot \mathrm{m}^{2}\right)$, em relação aos parcelamentos que não diferiram entre si.

Segundo Robinson (1996), a produção é, normalmente, o principal determinante do conteúdo de nutrientes pela cultura. $\mathrm{O}$ conteúdo máximo de $\mathrm{N}$ coincidiu com o período de máxima produção de MS (aplicação total em nov.), apesar da mesma, não ter diferido entre si em relação às épocas, no periodo do "verão".

Tabela 27. Extração de $P$ na matéria seca $\left(g \cdot \mathrm{m}^{2}\right)$ da parte área de Brachiaria humidicola, em função dos períodos estacionais (média de nove repetições).

\begin{tabular}{ll}
\hline \multicolumn{1}{c}{ Períodos $^{(1)}$} & \multicolumn{1}{c}{$\mathrm{P}^{(2)}\left(\mathrm{g} \cdot \mathrm{m}^{2}\right)$} \\
\hline "Verão" & $0,005 \mathrm{~A}$ \\
"Inverno" & $0,0006 \mathrm{~B}$ \\
C.V. $(\%)$ & 10,07 \\
\hline Médias de periodos seguidas de mesma letra maiúscula (coluna) não diferem entre si pelo teste t-Student ao nível de \\
0.05 de probabilidade.
\end{tabular}


Os resultados dos conteúdos de $\mathrm{P}$, de acordo com a Tabela 27 , diminuíram significativamente $(P<0,05)$ entre os periodos estudados, em virtude das quantidades terem sido influenciadas pelo produto dos teores de $\mathrm{P}\left(\mathrm{g} \cdot \mathrm{kg}^{-1}\right)$ pela produção de $\mathrm{MS}$.

$O$ fato da diminuição dos conteúdos de $P$ em função dos periodos podem ser atribuidas de acordo com Souza (1986b), às épocas em que as pastagens encontramse maduras ou secas quando os teores de $P$ sofrem grandes variações.

Tabela 28. Conteúdo de Ca na matéria seca $\left(g \cdot m^{2}\right)$ da parte área de Brachiaria humidicola, em função dos periodos e épocas de aplicação de nitrogênio (média de nove repetições).

\begin{tabular}{|c|c|c|c|}
\hline \multirow[b]{2}{*}{ Períodos } & \multicolumn{3}{|c|}{ Epocas } \\
\hline & $\begin{array}{c}\text { Aplicação Total } \\
\text { (Novembro) }\end{array}$ & $\begin{array}{c}\text { Parcelamento } \\
(1 / 2 \text { Nov. e 1/2 Mar.) }\end{array}$ & $\begin{array}{c}\text { Parcelamento } \\
\text { (1/3 Nov. e } 2 / 3 \text { Mar.) }\end{array}$ \\
\hline "Verão" & $0,006^{(2)} \mathrm{A} a$ & $0,005 \mathrm{~A} a$ & $0,005 \mathrm{~A} a$ \\
\hline "Inverno" & $0,0005 \mathrm{~A} \mathrm{~b}$ & $0,002 B C b$ & $0,002 \mathrm{Cb}$ \\
\hline C.V. (\%): & 9,02 & & \\
\hline
\end{tabular}

Na Tabela 28 , os conteúdos de Ca $\left(\mathrm{g} \cdot \mathrm{m}^{2}\right)$ diferiram significativamente $(P<0,05)$ para periodos, observando-se que no "inverno" os resultados obtidas, diferiram quanto à época aplicada, sendo o tratamento de aplicação total em nov. apresentado a menor concentração $\left(0,0005 \mathrm{~g} \cdot \mathrm{m}^{2}\right)$. 


\section{CONCLUSÕES}

\subsection{Panicum maximum cv. Mombaça}

Nas condições em que se desenvolveu o experimento, o capim Panicum maximum cv. Mombaça apresenta uma distribuição de produção de matéria seca mais equilibrada durante $\mathrm{o}$ ano, independente das épocas de aplicação de $\mathrm{N}$.

$O$ fato de não mostrar acentuada estacionalidade o capim Mombaça permite um melhor planejamento de uso durante $o$ ano.

Nestas condições, o capim Mombaça apresenta também uma distribuição equilibrada de produção de proteína nas épocas de "verão" e "inverno". 


\subsection{Brachiaria humidicola}

Nas condições em que se desenvolveu o experimento, o capim Brachiaria humidicola, apresenta acentuada estacionalidade de produção.

A produção de proteína bruta acompanha também acentuada estacionalidade apresentando maiores valores para o "verão".

As adubações parceladas de nitrogênio maiores $2 / 3$ no fim das águas (março), permitem atenuar a estacionalidade de produção. 


\section{REFERÊNCIAS BIBLIOGRÁFICAS}

ABRAMIDES, P.L.G.; BUFARAH, G.; BIANCHINE, D.; et al. Estudo da variação estacional da taxa diária d e matéria seca, dos teores de proteína e fibra bruta e da digestibilidade "in vivo" em Brachiaria humidicola (Rendle) Schweickdert. In: REUNIÃO ANUAL DA SOCIEDADE BRASILEIRA DE ZOOTECNIA, 20. Pelotas: SBZ, 1983. Anais. p.329.

ADDISON, K. B.; CAMERON, D.G.; BLIGHT, G.W. Effects of three levels of nitrogen and mowing on pasture and animal production from spring/summer grazed Panicum maximum var. Trichoglume (green panic) pastures Tropical Grasslands, v. 19, n. 2, p. $59-67,1985$.

AGUIAR, A. P.A. O uso do nitrogênio. Manejo da fertilidade do solo sob pastagem. Guaiba: Agropecuária, 1998. cap.5, p.87.

ANDRADE, J.B.; PEDREIRA, J.V.; HENRIQUE, W. Comparação de tres capins da espécie Panicum maximum Jacq. (Colonião, Tobiatã e K-187 B) sob dois niveis de adubação nitrogenada. Boletim da Indústria Animal, v.48, n.2, p.77-82, jul./dez. 1991.

ASSOCIATION OFFICIAL ANALYTICAL CHEMISTS. Offical methods of analysis. 16.ed. Washington: AOAC, 1995. 2v.

BATAGLIA, O.C. Determinação indireta de enxofre em plantas por espectrofotometria de absorção atômica. Ciência e Cultura, v.28, n.6, p.672-5, jun. 1976. 
BERGAMASCHINE, A.F.; ALVES, J.B.; ANDRADE, P. et al. Efeito da lotação sobre o desenvolvimento de novilhos guzerá recebendo suplementação múltiplo, durante a época seca.(compact disc). In: REUNIÃO ANUAL DA SOCIEDADE BRASILEIRA DE ZOOTECNIA, 35., Botucatu, 1998. Trabalhos. Botucatu: SBZ, 1998.

BOIN, C. Exigências de minerais pelas categorias do rebanho bovino e funções desses nutrientes. In: SIMPÓSIO SOBRE NUTRIÇÃO DE BOVINOS, 3. Piracicaba: 1985. Anais. Piracicaba: FEALQ, 1985, p.15-46.

BOIN, C. Produção animal em pastos adubados. . In: MATTOS, H.B. Ed. Calagem e adubação de pastagens. Piracicaba: Associação Brasileira para Pesquisa da Potassa e do Fosfato, 1986. p.384-419.

BRASIL. Ministério da Agricultura. Secretaria Nacional de Planejamento Agricola. Aptidão agrícola das terras de São Paulo. Brasilia: Binagri, 1979.

CARDOSO, E.C.; VALE, W.G.; McDOWEEL, L.R. et al. Seasonal variation of selenium, crude protein, and in vitro organic matter digestibility of Brachiaria humidicola from Marajo Island, Brazil. Communication in Soil Science and Plant Analysis, v. 28, n. 19/20, p. 1683-1691, 1997.

$\mathrm{CHURCH}$, D.C. El ruminante: fisiologia digestiva y nutricion. Zaragoza: Editorial ACRIBIA, 1993. 641p.

CORREA, L. A.; FREITAS, A. R.; BATISTA. L. A.R. Níveis de nitrogênio e freqüências de corte em 12 gramineas forrageiras tropicais. (compact disc). In: REUNIÃO ANUAL DA SOCIEDADE BRASILEIRA DE ZOOTECNIA, 35., Botucatu, 1998. Trabalhos. Botucatu: SBZ, 1998. p.304-306.

CORSI, M.; NÚSSIO, L.G. Manejo do capim-elefante: correção e adubação do solo. In: SIMPÓSIO SOBRE MANEJO DA PASTAGEM, 10. Piracicaba, 1992. Anais. Piracicaba: FEALQ, 1992 p.87-116.

CORSI, M.; SANTOS, P.M. Potencial de produção do Panicum maximum. In: SIMPÓSIO SOBRE MANEJO DA PASTAGEM, 12., Piracicaba, 1995. Anais. Piracicaba: FEALQ, 1995 p.275-303. 
COSTA, N. L. Produtividade e manejo de pastagens de Brachiaria humidicola no trópico Sul-americano. Porto Velho: EMBRAPA, CPAF, Rondônia,. 1997. 41p. (EMBRAPA-CPAF, Documentos, 37).

DAVISON, T.M.; SHEPHERD, R.K.; BROWN, G.W. Influence of frequency of nitrogen fertlizer application on milk from cows grazing tropical grass pastures. Tropical Grasslands, v.21, n. 1, p. 1-8. 1987.

DAVISON, T.M.; COWAN, R.T.; SHEPHERD, R.K. et al. Effects of stoking rate and level of nitrogen fertilizer on the pasture and diet. Australian Journal of Experimental Agriculture, v.25, p.505-514, 1985.

DIAS FILHO, M.B. Limitações e potencial de Brachiaria humidicola para o trópico úmido brasileiro. Belém: EMBRAPA, CPATU, 1983. 28p. (EMBRAPA. CPATU, Documentos, 20).

EUCLIDES, V.P.B. Valor alimentício de espécies forrageiras do gênero Panicum. In: SIMPÓSIO SOBRE MANEJO DA PASTAGEM, 12., Piracicaba, 1995. Anais. Piracicaba: FEALQ, 1995. p.245-274.

FALESI, I.C.; VEIGA, J.B. O solo da Amazônia e as pastagens cultivadas. In: PEIXOTO, A.M; MOURA, J.C. de; FARIA, V.P. de. (Ed.) Pastagens na Amazônia. Piracicaba: FEALQ, 1986. p.1-26.

FAVORETTO, V.; RODRIGUES, L.R.A.; TUPINAMBÁ, L.F. Efeito do nitrogênio na produção e composição bromatológica do capim-colonião e seus aspectos econômicos. Científica, v.16, n.1, p.71-78. 1988.

FOLLETT, R.F.; WILKINSON, S.R. Nutrient management of forages. In: BARNES, R.F.; MILLER, D.A.; NELSON, C.J. Forages: the science of grassland agriculture. 5.ed. lowa: lowa State University Press, 1995. v.2, p.55-82.

FORBES, J.M. Voluntary food intake and diet selection in farm animals. Wallingford: CAB International, 1995. 532p. 
GALLO, J.R.; HIROCE, R.; BATAGLIA, O.C. et al. Composição química inorgânica de forrageiras do Estado de São Paulo. Boletim da Indústria Animal, v.31, n.1, p.115-37, jan./jun. 1974.

GOMIDE, J.A. Mineral composition of grasses and tropical leguminous forages. In: LATIN AMERICAN SYMPOSIUM ON MINERAL NUTRITION RESEARCH WITH GRAZING RUMINANTS, Belo Horizonte, 1976. Proceedings. Gainesville: University of Florida, 1978. p.32-40.

GOMIDE, J.A; NOLLER, C.H.; MOTT, G.O. et al. Effect of plant age and nitrogen fertilization on the chemical composition and in vitro cellulose digestibility of tropical grasses. Agronomy Journal, v.61, n.1, p.116-20, Jan./Feb. 1969a.

GONÇALVES, C. A.; COSTA, N. de L; OLIVEIRA, J.R. da C. M;etodos de renovação de pastagens em Porto Velho, Rondônia. In: REUNIÓN DE LA RED INTERNACIONAL DE EVALUACIÓN DE PASTOS TROPICALES - AMAZONÍA, 1. Lima, 1990. Memórias. CIAT, 1990. v.2, p.593-595.

GUIMARÃES, P.T.G.; FERREIRA, J.G.; CARVALHO, J.G. de et al. Adubação de pastagens. Informe Agropecuário, v.6, n.70, p.47. 1980.

HAAG, H.P.; DECHEN, A.R. Deficiências minerais em plantas forrageiras. In: PEIXOTO, A.M.; MOURA, J.C. de; FARIA, V. P. de. Pastagens: fundamentos da exploração racional. 2.ed. Piracicaba: FEALQ, 1994. p.85-110. (FEALQ. Série atualização em zootecnia, 10).

HODGSON, J. Grazing management - Science into practice. New York: Longman Handbooks in Agriculture, Longman Scientific \& Technical., 1990. p.62-63.

HUMPHREYS, L.R. Tropical pasture utilization. Cambridge: Cambridge University Press, 1991. 120p.

ITALIANO, E.C.; SILVA, J.R. da. Rendimento forrageiro e composição química do capim quicuio-da-amazônia (Brachiaria humidicola) em diferentes estádios de crescimento. In: SIMPÓSIO DO TRÓPICO ÚMIDO, 1., Belém, 1984. Anais. Belém: EMBRAPA, CPATU, 1986 p.101-108. 
JANK, L. Melhoramento e seleção de variedades de Panicum maximum. In: SIMPÓSIO SPBRE MANEJO DA PASTAGEM, 12., Piracicaba, 1995. Anais. Piracicaba: FEALQ, 1995 p.21-58.

JANK, L.; SAVIDAN, Y.N.; SOUZA, M.T. de. et al. Avaliação do germoplasma de Panicum maximum introduzido da África. I. Produção forrageira. Revista da Sociedade Brasileira de Zootecnia, v. 23, n. 3, p. 433-440, 1994.

KOHAMN, C.; JACQUES, A.V.A. Rendimentos, qualidade e persistência de Panicum maximum Jacq. cv. Gatton e Setaria anceps Satpf. cv. Kazungula, colhidos em tres estádios de crescimento, a duas alturas de corte acima do solo e sob tres doses de nitrogênio. Anuário Técnico do IPZFO, v.6, p.229-343, dez. 1979.

LEITE, G.G.; GOMES, T.D.; SANTOS, C.A. dos. Produção de quatro cultivares de Brachiaria spp. nos cerrados. In: REUNIÃO ANUAL DA SOCIEDADE BRASILEIRA PARA O PROGRESSO DA CIÊNCIA, 38., Goiânia, 1981. Anais. Goiânia: SBPC. 1981. p. 110.

MABE, I.; FAVORETTO, V.; RODRIGUES, R. de A. Variação na disponibilidade de forragem e na composição botânica e bromatológica de pastagens exclusivas e consorciadas com capim colonião. Boletim da Indústria Animal, v.45, n.2, p.371380, jul./dez. 1988.

MACEDO, M.C.M; EUCLIDES, V.P.B.; OLIVEIRA, M.P. Seasonal changes in chemical composition of cultivated tropical grasses in the savannas of brazil. In : INTERNATIONAL GRASSLAND CONGRESS, 17., 1993. Parlmeston North. Proceedings....Parlmeston North: New Zealand Grassland Association, 1993. P. 2000-2002.

MALAVOLTA, E.; LIEM, T.H; PRIMAVESI, A.C.P.A. Exigências nutricionais das plantas forrageiras. In: MATTOS, H.B. (Ed.) Calagem e adubação de pastagens. Piracicaba: Associação Brasileira para Pesquisa da Potassa e do Fosfato, 1986. p.31-91. 
MALAVOLTA, E.; VITTI, G.C.; OLIVIERA, S.A. de. Avaliação do estado nutricional das plantas: princípios e aplicações. Piracicaba: Associação Brasileira para Pesquisa da Potassa e do Fosfato, 1989. 201p.

MATOS, A.O.; CAMARÃO, A.P.; BATISTA, H.A.M.B. Teores de minerais do capim quicuio-da-Amazônia (Brachiaria humidicola) em três idades de corte.. Belém: EMBRAPA, CPATU, 1987. 9p. (EMBRAPA. CPATU, Comunicado Técnico, 60).

MCDOWELL, L.R. Contribution of tropical forages and soil toward meeting mineral requirements of grazings ruminants. In: McDOWELL, L. R. Nutrition of grazing ruminants in warm climates. Orlando: Academic Press, 1985. P. 165-188.

MENGEL, K.; KIRKBY, E.A. Principles of plant nutrition. 4ed. Bern: International Potash Institute, 1987.687p.

MINSON, D.J. Composición química y valor nutritivo de las gramíneas tropicales. In: SKERMAN, P.J.; RIVEROS, F. Gramíneas tropicales. Roma: FAO, 1992. p.181-99. (Colección FAO: Producción Vegetal, 23).

MONTEIRO, F.A. Nutrição mineral e adubação. In: SIMPÓSIO SPBRE MANEJO DA PASTAGEM, 12., Piracicaba, 1995. Anais. Piracicaba: FEALQ, 1995. p.219-244.

MONTEIRO, F.A; WERNER, J.C. Efeitos das adubações nitrogenada e fosfatada em capim colonião, na formação e em pasto estabelecido. Boletim da Indústria Animal, v.34, n.1, p.91-101, jan./jun. 1977.

MONTEIRO, F.A; WERNER, J.C. Reciclagem de nutrientes nas pastagens. In: SIMPÓSIO SOBRE MANEJO DA PASTAGEM, 14., Piracicaba, 1995. Anais. Piracicaba: FEALQ, 1995. p.55-84.

NATIONAL RESEARCH COUNCIL. Nutrient requirements of beef cattle. 7.ed. Washington: National Academy of Science, 1996. 242p. (Nutrient Requeriments of Domestic Animals, 4). 
NORTON, B.W. Differences between species in forage quality. In: HACKER, J.B., (Ed.) Nutritional limits to animal production from pastures. Farnham Royal: CAB, 1982. p.89-110.

PAULINO, V.T.; BEISMAN, D.A.; FERRARI, Jr.,E. Fontes de nitrogênio na recuperação de pastagens de Brachiaria decumbens durante o período da seca. Pasturas Tropicales, v.17, n. 2, p.20-24,1995.

PAULINO, V.T.; SCHUNKE, R.; CANTARELLA, H. Avaliação do nivel de nitrogênio em quatro cultivares de Panicum maximum Jacq. através da medida indireta de clorofila. (compact disc). In: REUNIÃO ANUAL DA SOCIEDADE BRASILEIRA DE ZOOTECNIA, 35., Botucatu, 1998. Trabalhos. Botucatu: SBZ, 1998. p.427-429.

PEDREIRA, J.V.S. Crescimento estacional Crescimento estacional dos capins colonião Panicum maximum Jacq., gordura Melinis minutiflora Pal de Beauv, Jaraguá Hyparthenia rufa (Ness) Stapf e Pangola de Taiwan A-24 Digitaria Pentzii Stent. Boletim da Indústria Animal, v.30, n.1, p. 59-145, jan./jun. 1973.

PEDREIRA, J.V.S.; MATTOS, H.B. Crescimento estacional de vinte e cinco espécies ou variedades de capins. Boletim da Indústria Animal, v. 38. n. 2. jul./dez, p.117$143,1981$.

RAYMOND, W.F. The nutritive value of forage crops. Advances in Agronomy, v.21, p.1-108, 1969.

ROBINSON, D.L. Fertilization and nutrient utilization in harvested forage systems Southern forage crops. In: NUTRIENT CYCLING IN FORAGE SYSTEMS SYNPOSIUM, Columbia, 1996. Proceedings. Kansas: Potash and Phosphate Institute, Foundation for Agronomic research, 1996. p.65-92.

ROSSIELLO, R. O.P.; FERNANDES, M.S. Aspectos do metabolismo e utilização do nitrogênio em gramíneas tropicais. In : MATTOS, H.B. (Ed.) Calagem e adubação de pastagens. Piracicaba: Associação Brasileira para Pesquisa da Potassa e do Fosfato, 1986. p.91. 
SAMPAIO, E.V.S.B. Photossynthate partioning and growht in Pensacola bahiagrass. Athens, 1973. 93p. Thesis (PhD) - University of Georgia.

SANTOS, P.M. Estudo de algumas características agronômicas de Panicum maximum (Jacq.) cvs. Tanzânia e Mombaça para estabelecer seu manejo. Piracicaba, 1997. 62p. Dissertação (Mestrado) - Escola Superior de Agricultura "Luiz de Queiroz", Universidade de São Paulo.

SAS INSTITUTE. User's guide: statistics. release 6.03. Cary, 1988. 1028p.

SAVIDAN, Y.H.; JANK, L.; COSTA, J.C.G. Registros de 25 acessos selecionados de Panicum maximum, Campo Grande: EMBRAPA, CNPGC, 1990. 68p. (EMBRAPA, CNPGC, Documentos, 44).

SILVA, S.C. da. Condições edafo-climáticas para a produção de Panicum sp. In: SIMPÓSIO SOBRE MANEJO DA PASTAGEM, 12., Piracicaba, 1995. Anais. Piracicaba: FEALQ, 1995. p.129-146.

SIMÃO NETO, M.; SERRÃO, E.A.S. O capim Quicuio da Amazônia (Brachiaria sp.). Boletim Técnico. IPEAN, v.58, p.1-17, 1974.

SOARES, J.P.G.; PEREIRA, O.G.; AROEIRA, L.J.M. et al. Disponibilidade e composição química do capim-elefante (Pennisetum purpureum Schum.) sob pastejo, adubado com duas doses de nitrogênio. (compact disc). In: REUNIÃO ANUAL DA SOCIEDADE BRASILEIRA DE ZOOTECNIA, 35., Botucatu, 1998. Trabalhos. Botucatu: SBZ, 1998. p. 450-452.

SOUZA FILHO, A. P.S.; DUTRA, S.; SERRÃO, E. A.S. Produtividade estacional e composição botânica de Brachiaria humidicola e pastagem nativa de Campo Cerrado do Estado do Amapá, Brasil. Pasturas Tropicales v.14, n. p.11-16. 1992.

SOUZA, J.C. Composição mineral de Brachiaria em relação a outras gramineas. In: ENCONTRO PARA DISCUSSÃO SOBRE CAPINS DO GÊNERO Brachiaria. Nova Odessa: Instituto de Zootecnia, 1986a. cap. 4, 23p. 
SOUZA, J.C. Suplementação mineral na região amazônica. In: PEIXOTO, A.M; MOURA, J.C. de.; FARIA, V.P. de. (Ed.) Pastagens na Amazônia. Piracicaba: FEALQ, 1986b. p.56-69.

TEIXEIRA NETO, J.F.; NERY, A.P. Produtividade estacional da pastagem nativa e Brachiaria humidicola, na ilha de Marajó. In: REUNIÃO ANUAL DA SOCIEDADE BRASILEIRA DE ZOOTECNIA, 20., Pelotas, 1983. Anais. Pelotas: SBZ, 1983. p.305.

THOMAS, D.; ANDRADE, R.P. Desempenho agronômico de cinco gramíneas tropicais sob pastejo na região dos cerrados. Pesquisa Agropecuária Brasileira, v. 19, n. 8 . p. $1047-1051,1984$.

TOLEDO, J.M. Pasturas en Trópico Húmedo: perspectiva global. In: SIMPÓSIO DO TRÓPICO ÚMIDO, 1., Belém, 1984. Anais. Belém: EMBRAPA, CPATU, 1986. p.19-36.

UNDERSANDER, D.J.; HUTCHESON, D.P. Seasonal changes in composition of forage grasses on the southern high plains. Nutritional Reports International, v.30, n. 5. p.1101-1113. 1984.

VALENTIM, J.F.; MOREIRA, P. Vantagens e limitações dos capins Tanzânia e Mombaça para a formação de pastagens no Acre. EMBRAPA-CPAF, Acre, 1994, n. 60, ago., p.1-3. (EMBRAPA-CPAF, Comunicado Técnico, 60).

VAN SOEST, Nutritional ecology of the ruminant. 2 ed. Ithaca: Cornell University Press, 1994. 476p.

VENDRAMINI, J.M.B. Produção de matéria seca, digestibilidade "in vitro" e composição químico-bromatológica do capim Paspalum notatum cv. Tifton 9 em diferentes idades de crescimento. Piracicaba, 1999. 102p. Dissertação (Mestrado)

- Escola Superior de Agricultura "Luiz de Queiroz", Universidade de São Paulo.

VICENT-CHANDLER, J. Fertilization of humid tropical grasslands. In: MAYS, D. A. (Ed.) Forage fertilization. Madison: American Society of Agronomy. 1974. p. 277300 . 
VITTI, G.C.; NOVAES, N.J. Adubação com enxofre. In: MATTOS, H.B. (Ed.) Calagem e adubação de pastagens. Piracicaba: Associação Brasileira para Pesquisa da Potassa e do Fosfato, 1986. p.191-231p.

WERNER, J.C. Adubação de pastagens. Balde Branco, n.230, p. 40-48, dez. 1983.

WERNER, J.C. Estudo de épocas da adubação nitrogenada em capim colonião (Panicum maximum Jacq.) para aumento de produção de forragem nas secas. Boletim da Indústria Animal, v. 27/28. p. 361-367, 1970/71.

WISE, M.B.; ORDOREZA, A.L.; BARRICK, E.R. Influence of variations in dietary calcium:phosphorus ratio on performance and blood constituents of calves. Journal of Nutrition, v.79, n.1, p.79-85, jan. 1963. 